\title{
Cardiovascular Outcome in Patients Treated With SGLT2 Inhibitors for Heart Failure: A Meta-Analysis
}

\author{
Gloria M. Gager ${ }^{1,2}$, Georg Gelbenegger ${ }^{2}$, Bernd Jilma ${ }^{2}$, Dirk von Lewinski ${ }^{3}$, Harald Sourij ${ }^{4}$ \\ Ceren Eyileten ${ }^{5}$, Krzysztof Filipiak ${ }^{6}$, Marek Postula ${ }^{5}$ and Jolanta M. Siller-Matula ${ }^{1,5 *}$

\begin{abstract}
${ }^{1}$ Department of Internal Medicine II, Division of Cardiology, Medical University of Vienna, Vienna, Austria, ${ }^{2}$ Department of Clinical Pharmacology, Medical University of Vienna, Vienna, Austria, ${ }^{3}$ Department of Internal Medicine, Division of Cardiology, Medical University of Graz, Graz, Austria, ${ }^{4}$ Department of Internal Medicine, Division of Endocrinology and Diabetology, Medical University of Graz, Graz, Austria, ${ }^{5}$ Department of Experimental and Clinical Pharmacology, Medical University of Warsaw, Center for Preclinical Research and Technology CEPT, Warsaw, Poland, ${ }^{6}$ First Chair and Department of Cardiology, Medical University of Warsaw, Warsaw, Poland
\end{abstract}

OPEN ACCESS

Edited by:

Jingyan Han

Boston University, United States

Reviewed by:

Jena Brooke Goodman,

Boston University, United States

Lija Swain,

Tufts Medical Center, United States

Zhexue Qin,

Xinqiao Hospital, China

*Correspondence:

Jolanta M. Siller-Matula

jolanta.siller-matula@

meduniwien.ac.at

Specialty section:

This article was submitted to

Cardiovascular Therapeutics,

a section of the journal

Frontiers in Cardiovascular Medicine

Received: 07 April 2021

Accepted: 14 June 2021

Published: 14 July 2021

Citation:

Gager GM, Gelbenegger G, Jilma B, von Lewinski $D$, Sourij $H$, Eyileten $C$,

Filipiak K, Postula M and

Siller-Matula JM (2021)

Cardiovascular Outcome in Patients

Treated With SGLT2 Inhibitors for

Heart Failure: A Meta-Analysis.

Front. Cardiovasc. Med. 8:691907.

doi: $10.3389 / f c v m .2021 .691907$
Background: Sodium-glucose co-transporter 2 (SGLT2) inhibitors are an emerging class of glucose-lowering drugs that have become increasingly relevant for the treatment and prevention of heart failure (HF). Therefore, we aimed to investigate various SGLT2 inhibitors in patients with established HF at baseline and focused on the different types of HF.

Methods: An extensive search of PubMed and Web of Science until January 2021 was done. Two reviewers, independently and in duplicate, applied the selection criteria. This meta-analysis was conducted according to the PRISMA guidelines. Data were pooled using a random-effects model. Randomized controlled trials (RCTs) of SGLT2 inhibitors vs. a comparator in patients with HF reporting clinical outcomes were included. The primary efficacy outcome was the composite of hospitalization for HF (HHF) or cardiovascular (CV) mortality. All-cause mortality, CV mortality, and HHF were considered as secondary endpoints. Subgroup analyses involving the status of diabetes, type of HF, administered type of SGLT2 inhibitor, sex, age, body mass index (BMI), estimated glomerular filtration rate (eGFR), cause of HF, and concomitant medication were performed.

Results: Seventeen RCTs, comprising a total of 20,749 participants, were included ( $n=10,848$ treated with SGLT2 inhibitors and $n=9,901$ treated with a comparator). Treatment with SGLT2 inhibitors in a HF population was associated with a 27\% relative risk reduction (RRR) of $\mathrm{HHF}$ or $\mathrm{CV}$ mortality [risk ratio $(\mathrm{RR})=0.73,95 \% \mathrm{Cl}=0.68-$ 0.78], 32\% RRR of HHF (RR $=0.68,95 \% \mathrm{Cl}=0.62-074), 18 \%$ RRR of CV mortality $(R R=0.82,95 \% \mathrm{Cl}=0.73-0.91)$, and $17 \% \mathrm{RRR}$ of all-cause mortality $(R R=0.83,95 \%$ $\mathrm{Cl}=0.75-0.91)$. The effect of SGLT2 inhibitors on the primary endpoint was consistent among the different gliflozines. The effect of SGLT2 inhibitors on the primary endpoint was independent of underlying diabetes mellitus, age, sex, BMI, renal function, and HF type.

Conclusions: SGLT2 inhibitors are associated with improved CV outcomes in patients with HF.

Keywords: SGLT2 inhibitors, clinical outcome, heart failure, pharmacotherapy, meta-analysis 


\section{BACKGROUND}

Sodium-glucose co-transporter 2 (SGLT2) inhibitors are an arising drug class across antidiabetic therapeutics. During the last five years, large randomized trials have shown the cardioprotective effects of three SGLT2 inhibitorsempagliflozin, dapagliflozin, and canagliflozin-independently of the presence or absence of diabetes mellitus (DM) and within the first months after initiating the treatment (1-5). Recently, these benefits have also been demonstrated for sotagliflozin and ertugliflozin (6-8). The glucose-lowering effects of these agents are mediated through the inhibition of renal glucose reuptake in the proximal tubule of the nephron, which consequently leads to a decrease in blood glucose levels (9-11). However, it is assumed that the cardioprotective properties are of a different origin from the promoted urine glucose excretion. Although, a variety of hypotheses for SGLT2 inhibitor-induced benefits exist, the exact underlying mechanism is unclear (12). Aside from the impact on blood pressure and body weight, modulation of ion homeostasis and cellular processes are suggested (13). In particular, SGLT2 inhibitors have become progressively interesting for the treatment and prevention of heart failure (HF) (14), which has emerged as a global health issue. According to the most recent European Society of Cardiology (ESC) guidelines, $\mathrm{HF}$ is prevalent in $2 \%$ of the adult population and is more frequent in patients with atrial fibrillation $(15,16)$. Although, survival after onset of HF improved over the last 50 years (17), the 12 -month all-cause mortality still occurs in about $7 \%$ of patients diagnosed with chronic $\mathrm{HF}$ and in $17 \%$ of patients suffering from acute HF (18-22).

Due to the promising results of the EMPA-REG OUTCOME, DECLARE-TIMI 58, CANVAS and CREDENCE trials regarding their cardiovascular (CV) outcomes in patient populations with and without HF, the next logical aim was to put focus on subgroups with an established HF at baseline, as in the DAPA-HF, EMPEROR-Reduced, and SOLOIST-WHF trials (16). In this respect, we performed a systematic review and meta-analysis of randomized controlled trials (RCTs) that investigated SGLT2 inhibitors in patients with established HF regarding their clinical endpoints, with a particular focus on the type of HF.

\section{METHODS}

The following systematic review and meta-analysis was conducted in accordance with the Preferred Reporting Items for Systematic Reviews and Meta-Analyses (PRISMA) guidelines, as described previously (23-28). We performed an extensive

Abbreviations: SGLT2, sodium-glucose co-transporter 2; T2DM, type 2 diabetes mellitus; HF, heart failure; HHF, hospitalization for heart failure; CV, cardiovascular; RCT, randomized controlled trial; RR, relative risk; RRR, relative risk reduction; ARR, absolute risk reduction; EF, ejection fraction; HFpEF, HF with preserved ejection fraction; HFmrEF, HF with mid-range ejection fraction; HFrEF, HF with reduced ejection fraction; ARNI, angiotensin receptor neprilysin inhibitor; MRA, mineralocorticoid receptor antagonist; NNT, number needed to treat; $\mathrm{CI}$, confidence interval; $\mathrm{HR}$, hazard ratio; eGFR, estimated glomerular filtration rate; $\mathrm{BMI}$, body mass index. search of PubMed and Web of Science, applying predefined search terms [(empagliflozin OR dapagliflozin OR canagliflozin OR ertugliflozin OR sotagliflozin) AND heart failure AND randomized controlled trial], until January 2021. The title and abstract of suspected relevant citations were screened for eligibility, and full-text was acquired for further evaluation if the citation was deemed pertinent. The references of the retrieved meta-analyses and reviews were also examined for additional trials.

All included studies had to be RCTs, regardless of sample size, and follow-up time, comparing SGLT2 inhibitors either to placebo or a comparator and evaluated clinical endpoints. The eligible patient population for our meta-analysis comprised patients with any diagnosed HF at baseline. Two reviewers (GMG and JMSM), independently and in duplicate, applied the selection criteria. The exclusion criteria were: non-RCTs, duplicate reports, ongoing studies, studies that included patients without HF, and studies that did not assess clinical endpoints.

The primary efficacy endpoint of our meta-analysis was a composite of $\mathrm{CV}$ mortality or hospitalization for $\mathrm{HF}$ (HHF). This primary composite endpoint of $\mathrm{HHF}$ or $\mathrm{CV}$ mortality was chosen based on a uniform definition of the primary endpoint used in the majority of HF trials, which was also used in the large RCTs included into our metaanalysis. CV mortality, all-cause mortality, and HHF were considered as our secondary endpoints. For further analysis of the data, we performed subgroup analyses involving the status of diabetes, type of HF, and type of SGLT2 inhibitors used.

\section{Statistical Analysis}

Variables are reported as number or percentages, as applicable. Risk ratios (RRs) were calculated from individual studies and pooled according to the inverse variance model with 95\% confidence intervals ( $95 \% \mathrm{CI}$ ) and reported as relative risk reduction (RRR), as reported previously (28-32). The statistical inconsistency test $\left(I^{2}\right)$ was used for the assessment of any heterogeneity between the studies. We used a randomeffects model for all analyses. The following sensitivity analyses were performed: (i) comparison of the results of fixed- vs. random-effects model; (ii) assessment of each study influence by successively deleting one by one to evaluate whether the pooled results of the meta-analysis change significantly; and (iii) introduction of the following subgroups: SGLT2 inhibitor type, DM vs. no DM, HF with reduced ejection fraction (HFrEF), HF with mid-range ejection fraction (HFmrEF), HF with preserved ejection fraction (HFpEF), sex, age, body mass index (BMI), estimated glomerular filtration rate (eGFR), cause of $\mathrm{HF}$, and concomitant medication. We also calculated a number needed to treat (NNT) for the composite endpoint based on the mathematical formula: $\mathrm{NNT}=1$ /absolute risk reduction (ARR). A two-tailed $p$-value of $<0.05$ was considered as significant. Review Manager (version 5.4; Copenhagen: The Nordic Cochrane Centre, The Cochrane Collaboration 2020) was used for statistical computations. 


\section{RESULTS}

\section{Study Selection}

Our literature search retrieved 514 references, of which 256 articles were studied more precisely based on their title or abstract (Supplementary Figure 1). The remaining references were excluded for the following reasons: non-RCTs, no clinical endpoints or not differentiating between patients with or without $\mathrm{HF}$ at baseline. Additionally, the retrieved reviews and metaanalyses were examined thoroughly to identify further trials, investigating the chosen topic. Seventeen trials (1-8, 33-41) were eligible for our meta-analysis, including an overall patient population of 20,749 participants, of which 10,848 patients were assigned to the SGLT2 inhibitor group and 9,901 participants were allocated to the control group (Supplementary Figure 2). The mean age of the included patient population was 67 years, whereas, the mean follow-up period comprised 18 months (ranging from 2 to 50.4 months). Our meta-analysis included three large clinical trials, which were performed only in HF participants: DAPA-HF, EMPEROR-Reduced, and SOLOISTWHF $(2,6,34)$. Furthermore, we covered data from post-hoc and subgroup analyses of the EMPA-REG OUTCOME (42), DECLARE-TIMI 58 (43), CANVAS (44), CREDENCE (45), VERTIS-CV (46), and SCORED (8) trials. Additionally to the regular DAPA-HF trial (2), two post-hoc analyses of DAPA-HF $(47,48)$ for our diabetes and concomitant medication subgroups were used. Furthermore, we included eight smaller studies, which were solely performed on patients with $\mathrm{HF}$ at baseline with or without type 2 diabetes mellitus (T2DM) (33, 35-41). Only the CANDLE Study was active comparator-controlled instead of placebo-controlled (41). The included studies are characterized in Table 1.

\section{Outcomes}

Primary Composite Outcome: Hospitalization for Heart Failure or Cardiovascular Death

The composite outcome of HHF or CV death was regarded as our primary endpoint. Ten trials $(2,4,6,8,34,35,42-$ $44,46)$ reported on the primary efficacy outcome. Overall, $17 \%$ of patients experienced HHF or CV death under treatment with SGLT2 inhibitors as compared to $23 \%$ in the control-group, resulting in a $\mathrm{RRR}$ of $27 \%(\mathrm{RR}=0.73,95 \% \mathrm{CI}=0.68-0.78$, $p<0.00001, I^{2}=0 \%$ ) (Figure 1A) and an ARR of $6 \%$. This corresponds to a NNT of 17. For a group of 1,000 patients treated with SGLT2 inhibitors for HF for a mean time of 18 months, the composite endpoint of HHF or CV death could be prevented in 60 (Table 2).

\section{Hospitalization for Heart Failure}

Thirteen trials $(2,6,33,34,37,39-41,43-46,49)$ provided data on the incidence of HHF. In the patient population assigned to SGLT2 inhibitors, $11 \%$ experienced HHF. In contrast, $16 \%$ patients who were allocated to the control group were hospitalized due to HF. SGLT2 inhibitor use therefore resulted in a RRR of HHF by $32 \%(\mathrm{RR}=0.68,95 \% \mathrm{CI}=0.62-0.74, p<$ $0.00001, I^{2}=0 \%$ ) (Figure 1B) and an ARR of $4 \%$.

\section{Cardiovascular Mortality}

Overall, 10 trials reported on CV mortality $(2,6,34,36,38-$ $40,43,44,49)$. Treatment with SGLT2 inhibitors was associated with a RRR of $18 \%$ to die from CV causes $(\mathrm{RR}=0.82,95 \% \mathrm{CI}=$ $0.73-0.91, p<0.001, I^{2}=0 \%$ ) (Figure 1C) and an ARR of $2 \%$. When treated with SGLT2 inhibitors, CV mortality occurred in $9 \%$ of patients as compared to $11 \%$ of patients allocated to the comparison group.

\section{All-Cause Mortality}

In patients treated with SGLT2 inhibitors, all-cause mortality was reported in $11 \%$ as compared to $13 \%$ in patients treated with placebo or a comparator. Consequently, the RRR to die from any cause was $17 \%(\mathrm{RR}=0.83,95 \% \mathrm{CI}=0.75-0.91, p<0.001$, $I^{2}=0 \%$ ) (Figure 1D) with an ARR of $2 \%$, when assigned to SGLT2 inhibitors.

\section{Main Analyses for the Primary Composite Endpoint}

\section{Status of Diabetes Mellitus}

We investigated the composite endpoint of $\mathrm{HHF}$ or $\mathrm{CV}$ death in populations with and without DM. Both groups showed statistically significant results for treatment with SGLT2 inhibitors, but the magnitude of the effect was numerically, albeit not statistically, larger in patients with $\mathrm{DM}(\mathrm{RRR}=28 \%, \mathrm{RR}=$ $\left.0.72,95 \% \mathrm{CI}=0.67-0.78, p<0.00001, I^{2}=0 \%\right)$ as compared to patients without $\mathrm{DM}(\mathrm{RRR}=24 \%, \mathrm{RR}=0.76,95 \% \mathrm{CI}=0.66-$ $0.87, p<0.0001, I^{2}=0 \%$, $p$-value for subgroup differences $=$ 0.60 ) (Figure 2A), with an ARR of $7 \%$.

\section{Type of Heart Failure}

Subgroup analysis for the composite endpoint was also performed considering the type of HF (Figure 2B). SGLT2 inhibitors worked comparably well in patients diagnosed with HFrEF ( $\mathrm{EF} \leq 40 \%$ and $\leq 45 \%$, respectively), with a resulting RRR of $26 \%\left(\mathrm{RR}=0.74,95 \% \mathrm{CI}=0.68-0.81, p<0.00001, I^{2}=0 \%\right)$, in patients with $\mathrm{HFpEF}$ ( $\mathrm{EF}>45 \%$ and $>50 \%$, respectively), with a RRR of $27 \%\left(\mathrm{RR}=0.73,95 \% \mathrm{CI}=0.59-0.91, p=0.005, I^{2}=\right.$ $0 \%$ ), and in patients with an unknown (not specified) EF, with a $\mathrm{RRR}$ of $26 \%(\mathrm{RR}=0.74,95 \% \mathrm{CI}=0.63-0.87, p=0.0002$, $\left.I^{2}=8 \%\right)$. In patients with acute HF, SGLT2 inhibitors were even more beneficial $(\mathrm{RRR}=33 \%, \mathrm{RR}=0.67,95 \% \mathrm{CI}=0.52-$ $0.86, p=0.002)$. The greatest effects were seen in participants diagnosed with $\mathrm{HFmrEF}(\mathrm{EF}=40-50 \%)$, leading to a RRR of $42 \%\left(\mathrm{RR}=0.58,95 \% \mathrm{CI}=0.40-0.83, p=0.003, I^{2}=2 \%\right)$.

The differences between the individual subgroups were not deemed statistically significant $(p=0.69)$.

\section{Analyses for Type of SGLT2 Inhibitor Primary Composite Outcome: Hospitalization for Heart Failure or Cardiovascular Death}

The direction of the effect of SGLT2 inhibition on the composite endpoint was comparable for all five agents (Figure 3A). The magnitude of the effect was similar between dapagliflozin (RRR $=28 \%, \mathrm{RR}=0.72,95 \% \mathrm{CI}=0.63-0.82, p<0.00001, I^{2}=$ $6 \%)$, sotagliflozin $(\mathrm{RRR}=28 \%, \mathrm{RR}=0.72,95 \% \mathrm{CI}=0.61-0.84$, $\left.p<0.0001, I^{2}=0 \%\right)$, and empagliflozin $(\mathrm{RRR}=26 \%, \mathrm{RR}=$ 
TABLE 1 | Characteristics of the included studies.

\begin{tabular}{|c|c|c|c|c|c|c|c|c|c|c|}
\hline Study & Study drug & $\begin{array}{l}\text { Study drug } \\
\text { treatment } \\
\text { regimen }\end{array}$ & $\begin{array}{l}\text { Control } \\
\text { agent }\end{array}$ & Study design & $\begin{array}{l}\text { Trial } \\
\text { participants, } \\
n\end{array}$ & $\begin{array}{l}\text { Participants } \\
\text { with HF at } \\
\text { baseline, } n(\%)\end{array}$ & Type of HF & $\begin{array}{l}\text { Participants } \\
\text { with T2DM at } \\
\text { baseline, } n(\%)\end{array}$ & $\begin{array}{l}\text { Median } \\
\text { follow-up }\end{array}$ & $\begin{array}{l}\text { Median } \\
\text { age } \\
\text { (years) }\end{array}$ \\
\hline $\begin{array}{l}\text { Zinman et al. (1) } \\
\text { EMPA-REG OUTCOME } \\
\text { Fitchett et al. (42) } \\
\text { Post-hoc analysis }\end{array}$ & Empagliflozin & $\begin{array}{l}10 \text { or } 25 \mathrm{mg} \\
\text { once daily }\end{array}$ & Placebo & Double-blind RCT & 7,020 & 706 (10.1) & Not specified & $7,020(100)$ & 3.1 years & 63 \\
\hline $\begin{array}{l}\text { Dammann et al. (33) } \\
\text { EMPA-RESPONSE-AHF }\end{array}$ & Empagliflozin & $\begin{array}{l}10 \mathrm{mg} \\
\text { once daily }\end{array}$ & Placebo & Double-blind RCT & 79 & $79(100)$ & Acute HF & $26(33)$ & 60 days & 76 \\
\hline $\begin{array}{l}\text { Packer et al. (34) } \\
\text { EMPEROR-Reduced }\end{array}$ & Empagliflozin & $\begin{array}{l}10 \mathrm{mg} \\
\text { once daily }\end{array}$ & Placebo & Double-blind RCT & 3,730 & $3,730(100)$ & HFrEF & $1,856(50)$ & 16 months & 67 \\
\hline $\begin{array}{l}\text { Abraham et al. (35) } \\
\text { EMPERIAL-Reduced }\end{array}$ & Empagliflozin & $\begin{array}{l}10 \mathrm{mg} \\
\text { once daily }\end{array}$ & Placebo & Double-blind RCT & 312 & $312(100)$ & HFrEF & $187(60)$ & 12 weeks & 69 \\
\hline $\begin{array}{l}\text { Jensen et al. (36) } \\
\text { EMPIRE-HF }\end{array}$ & Empagliflozin & $\begin{array}{l}10 \mathrm{mg} \\
\text { once daily }\end{array}$ & Placebo & Double-blind RCT & 190 & $190(100)$ & HFrEF & $33(17)$ & 12 weeks & 64 \\
\hline $\begin{array}{l}\text { Mordi et al. (37) } \\
\text { RECEDE-CHF }\end{array}$ & Empagliflozin & $\begin{array}{l}25 \mathrm{mg} \\
\text { once daily }\end{array}$ & Placebo & Double-blind RCT & 23 & $23(100)$ & HFrEF & $23(100)$ & 12 weeks & 70 \\
\hline $\begin{array}{l}\text { Lee et al. (38) } \\
\text { SUGAR-DM-HF }\end{array}$ & Empagliflozin & $\begin{array}{l}10 \mathrm{mg} \\
\text { once daily }\end{array}$ & Placebo & Double-blind RCT & 105 & 105 (100) & HFrEF & $82(78)$ & 36 weeks & 69 \\
\hline $\begin{array}{l}\text { McMurray et al. (2) } \\
\text { DAPA-HF } \\
\text { Petrie et al. (47) } \\
\text { Post-hoc analysis } \\
\text { Docherty et al. (48) } \\
\text { Post-hoc analysis }\end{array}$ & Dapagliflozin & $\begin{array}{l}10 \mathrm{mg} \\
\text { once daily }\end{array}$ & Placebo & Double-blind RCT & 4,744 & $4,744(100)$ & $\mathrm{HFrEF}$ & 2,139 (45) & 1.5 years & 66 \\
\hline $\begin{array}{l}\text { Wiviott et al. (3) } \\
\text { DECLARE-TIMI } 58 \\
\text { Kato et al. (43) } \\
\text { Post-hoc analysis }\end{array}$ & Dapagliflozin & $\begin{array}{l}10 \mathrm{mg} \\
\text { once daily }\end{array}$ & Placebo & Double-blind RCT & 17,160 & $1,724(10)$ & $\begin{array}{l}\text { HFrEF HF with } \\
\text { unknown EF }\end{array}$ & $17,160(100)$ & 4.2 years & 64 \\
\hline $\begin{array}{l}\text { Nassif et al. (39) } \\
\text { DEFINE-HF }\end{array}$ & Dapagliflozin & $\begin{array}{l}10 \mathrm{mg} \\
\text { once daily }\end{array}$ & Placebo & Double-blind RCT & 263 & $263(100)$ & HFrEF & $166(63)$ & 12 weeks & 61 \\
\hline $\begin{array}{l}\text { Singh et al. (40) } \\
\text { REFORM }\end{array}$ & Dapagliflozin & $\begin{array}{l}10 \mathrm{mg} \\
\text { once daily }\end{array}$ & Placebo & Double-blind RCT & 56 & $56(100)$ & HFrEF & $56(100)$ & 1 year & 67 \\
\hline $\begin{array}{l}\text { Neal et al. (5) } \\
\text { CANVAS } \\
\text { Radholm et al. (44) } \\
\text { Post-hoc analysis }\end{array}$ & Canagliflozin & $\begin{array}{l}100 \text { or } \\
300 \mathrm{mg} \\
\text { once daily }\end{array}$ & Placebo & Double-blind RCT & 10,142 & 1,461 (14.4) & Not specified & 10,142 (100) & 3.6 years & 64 \\
\hline $\begin{array}{l}\text { Perkovic et al. (4) } \\
\text { CREDENCE } \\
\text { Sarraju et al. (45) } \\
\text { Post-hoc analysis }\end{array}$ & Canagliflozin & $\begin{array}{l}100 \mathrm{mg} \\
\text { once daily }\end{array}$ & Placebo & Double-blind RCT & 4,401 & $652(15)$ & Not specified & $4,401(100)$ & 2.6 years & 63 \\
\hline $\begin{array}{l}\text { Tanaka et al. (41) } \\
\text { CANDLE }\end{array}$ & Canagliflozin & $\begin{array}{l}100 \mathrm{mg} \\
\text { once daily }\end{array}$ & Glimepiride & Open-label RCT & 241 & $241(100)$ & HFrEF, HFpEF & $241(100)$ & 24 weeks & 69 \\
\hline
\end{tabular}


$0.74,95 \% \mathrm{CI}=0.65-0.84, p<0.00001, I^{2}=0 \%$ ). Canagliflozin was associated with the highest RRR of $31 \%$ as compared to the control arm $\left(\mathrm{RR}=0.69,95 \% \mathrm{CI}=0.53-0.90, p=0.007, I^{2}\right.$ $=34 \%$ ) in post-hoc analyses of the RCTs. Ertugliflozin missed statistical significance $(p=0.22)$.

\section{Hospitalization for Heart Failure}

All five agents reached significant values for the prevention of HHF as compared to the control arm (Figure 3B). Again, canagliflozin was demonstrated to have the greatest effects on this endpoint, with a RRR of $39 \%(\mathrm{RR}=0.61,95 \% \mathrm{CI}=0.45-$ $\left.0.84, p=0.002, I^{2}=0 \%\right)$, followed by ertugliflozin (RRR = $37 \%, \mathrm{RR}=0.63,95 \% \mathrm{CI}=0.44-0.90, p=0.01$ ) and sotagliflozin $(\mathrm{RRR}=36 \%, \mathrm{RR}=0.64,95 \% \mathrm{CI}=0.48-0.84, p=0.001)$. The magnitude of the effect was similar between dapagliflozin (RRR $\left.=31 \%, \mathrm{RR}=0.69,95 \% \mathrm{CI}=0.57-0.85, p=0.0004, I^{2}=8 \%\right)$, and empagliflozin $(\mathrm{RRR}=30 \%, \mathrm{RR}=0.70,95 \% \mathrm{CI}=0.60-0.81$, $\left.p<0.00001, I^{2}=0 \%\right)$.

\section{Cardiovascular Mortality}

Although, the direction of the effect was similar for all the tested agents, empagliflozin, canagliflozin, and sotagliflozin did not reach statistical significance for the reduction of $\mathrm{CV}$ mortality ( $p=0.24,0.07$, and 0.37 , respectively). Dapagliflozin showed borderline significance, obtaining a $29 \%$ RRR of death from CV causes $\left(\mathrm{RR}=0.71,95 \% \mathrm{CI}=0.52-0.98, p=0.04, I^{2}=24 \%\right)$ (Figure 4A).

\section{All-Cause Mortality}

Although, the direction of the effect was similar for all the tested agents, the magnitude of the benefit differed between the different SGLT2 inhibitors (Figure 4B). Canagliflozin showed a RRR of $23 \%\left(\mathrm{RR}=0.77,95 \% \mathrm{CI}=0.60-0.99, p=0.04, I^{2}=0 \%\right)$ and dapagliflozin a RRR of $21 \%(\mathrm{RR}=0.79,95 \% \mathrm{CI}=0.79-0.91, p=$ $\left.0.001, I^{2}=55 \%\right)$ for all-cause mortality. However, empagliflozin and sotagliflozin did not reach statistical significance for the reduction of all-cause mortality ( $p=0.19$ and 0.24 , respectively).

\section{Subgroup Analyses for the Primary Composite Outcome According to Patients' Baseline Data \\ Sex}

Both men and women profited from treatment with SGLT2 inhibitors. As shown in Figure 5A, these benefits were even more pronounced in the female population, with a resulting RRR of $30 \%\left(\mathrm{RR}=0.70,95 \% \mathrm{CI}=0.57-0.86, p=0.0007, I^{2}=13 \%\right)$ as compared to a RRR of $26 \%$ in male patients $(\mathrm{RR}=0.74,95 \% \mathrm{CI}$ $\left.=0.65-0.84, p<0.00001, I^{2}=25 \%\right)$.

\section{Age}

As shown in Figure 5B, the SGLT2 inhibitors reached statistical significance in patients $<65$ years of age and in patients 65 years or older for the reduction of the composite endpoint, with RRRs of $25 \%$ and $28 \%$, respectively $(\mathrm{RR}=0.75,95 \% \mathrm{CI}=0.65$ $0.86, p<0.0001, I^{2}=0 \%$; RR $=0.72,95 \% \mathrm{CI}=0.65-0.81$, $p<0.00001, I^{2}=0 \%$ ). 
A

\begin{tabular}{|c|c|c|c|c|}
\hline Study or Subgroup & log[Risk Ratio] & SE & Weight & $\begin{array}{c}\text { Risk Ratio } \\
\text { IV, Random, } 95 \% \mathrm{CI}\end{array}$ \\
\hline CANVAS, 2017 & -0.49 & 0.14 & $6.5 \%$ & $0.61[0.47,0.81]$ \\
\hline DECLARE-TIMI 58, 2019 & -0.48 & 0.16 & $5.0 \%$ & $0.62[0.45,0.85]$ \\
\hline SOLOIST-WHF, 2020 & -0.4 & 0.13 & $7.6 \%$ & $0.67[0.52,0.86]$ \\
\hline EMPERIAL-Reduced, 2020 & -0.37 & 0.4 & $0.8 \%$ & $0.69[0.32,1.51]$ \\
\hline EMPA-REG OUTCOME, 2015 & -0.33 & 0.19 & $3.5 \%$ & $0.72[0.50,1.04]$ \\
\hline DAPA-HF, 2019 & -0.3 & 0.07 & $26.1 \%$ & $0.74[0.65,0.85]$ \\
\hline EMPEROR-Reduced, 2020 & -0.29 & 0.07 & $26.1 \%$ & $0.75[0.65,0.86]$ \\
\hline SCORED, 2020 & -0.29 & 0.1 & $12.8 \%$ & $0.75[0.62,0.91]$ \\
\hline CREDENCE, 2019 & -0.21 & 0.18 & $3.9 \%$ & $0.81[0.57,1.15]$ \\
\hline VERTIS CV, 2020 & -0.16 & 0.13 & $7.6 \%$ & $0.85[0.66,1.10]$ \\
\hline Total $(95 \% \mathrm{Cl})$ & & & $100.0 \%$ & $0.73[0.68,0.78$ \\
\hline
\end{tabular}

Test for overall effect: $Z=8.74(P<0.00001)$

B

\begin{tabular}{l} 
Study or Subgroup \\
\hline CANDLE, 2020 \\
EMPA-RESPONSE-AHF, 2019 \\
CANVAS, 2017 \\
VERTIS CV, 2020 \\
DECLARE-TIMI 58, 2019 \\
SOLOIST-WHF, 2020 \\
EMPEROR-Reduced, 2020 \\
DAPA-HF, 2019 \\
EMPA-REG OUTCOME, 2015 \\
CREDENCE, 2019 \\
REFORM Trial, 2020 \\
DEFINE-HF, 2019 \\
RECEDE-CHF, 2020
\end{tabular}

Total $(95 \% \mathrm{Cl})$

Heterogeneity: $\mathrm{Tau}^{2}=0.00 ; \mathrm{Chi}^{2}=6.88, \mathrm{df}=12(\mathrm{P}=0.87) ; \mathrm{I}^{2}=0 \%$
Test for overall effect: $\mathrm{Z}=8.22(\mathrm{P}<0.00001)$

$\begin{array}{ccc}\text { Risk Ratio } \\ \text { log[Risk Ratio] } & \text { SE Weight } & \text { IV, Random, 95\% C }\end{array}$

$\begin{array}{rrrr}-1.05 & 1.81 & 0.1 \% & 0.35[0.01,12.15] \\ -0.94 & 0.81 & 0.3 \% & 0.39[0.08,1.91] \\ -0.67 & 0.22 & 4.6 \% & 0.51[0.33,0.79] \\ -0.46 & 0.18 & 6.8 \% & 0.63[0.44,0.90] \\ -0.45 & 0.2 & 5.5 \% & 0.64[0.43,0.94] \\ -0.45 & 0.14 & 11.3 \% & 0.64[0.48,0.84] \\ -0.37 & 0.08 & 34.6 \% & 0.69[0.59,0.81] \\ -0.36 & 0.09 & 27.4 \% & 0.70[0.58,0.83] \\ -0.29 & 0.23 & 4.2 \% & 0.75[0.48,1.17] \\ -0.27 & 0.24 & 3.8 \% & 0.76[0.48,1.22] \\ 0 & 1.36 & 0.1 \% & 1.00[0.07,14.38] \\ 0.23 & 0.46 & 1.0 \% & 1.26[0.51,3.10] \\ 1.61 & 1.52 & 0.1 \% & 5.00[0.25,98.41]\end{array}$

$100.0 \% \quad 0.68[0.62,0.74]$

C

\begin{tabular}{l} 
Study or Subgroup \\
\hline REFORM Trial, 2020 \\
DECLARE-TIMI 58, 2019 \\
EMPA-REC OUTCOME, 2015 \\
CANVAS, 2017 \\
DAPA-HF, 2019 \\
SOLOIST-WHF, 2020 \\
EMPEROR-Reduced, 2020 \\
EMPIRE-HF, 2020 \\
DEFINE-HF, 2019 \\
SUGAR-DM-HF, 2020
\end{tabular}

Total $(95 \% \mathrm{Cl})$

Heterogeneity: $\mathrm{Tau}^{2}=0.00 ; \mathrm{Chi}^{2}=7.27, \mathrm{df}=9(\mathrm{P}=0.61) ; \mathrm{I}^{2}=0 \%$

Test for overall effect: $Z=3.54(P=0.0004)$

\begin{tabular}{|c|c|c|c|}
\hline $\log$ [Risk Ratio] & SE & Weight & $\begin{array}{c}\text { Risk Ratio } \\
\text { IV, Random, } 95 \% \text { CI }\end{array}$ \\
\hline-1.97 & 1.35 & $0.2 \%$ & $0.14[0.01,1.97]$ \\
\hline-0.6 & 0.25 & $5.1 \%$ & $0.55[0.34,0.90]$ \\
\hline-0.34 & 0.26 & $4.7 \%$ & $0.71[0.43,1.18]$ \\
\hline-0.33 & 0.18 & $9.8 \%$ & $0.72[0.51,1.02]$ \\
\hline-0.2 & 0.09 & $39.3 \%$ & $0.82[0.69,0.98]$ \\
\hline-0.17 & 0.19 & $8.8 \%$ & $0.84[0.58,1.22]$ \\
\hline-0.08 & 0.1 & $31.8 \%$ & $0.92[0.76,1.12]$ \\
\hline 0 & 2 & $0.1 \%$ & $1.00[0.02,50.40]$ \\
\hline 0.01 & 1.44 & $0.2 \%$ & $1.01[0.06,16.99]$ \\
\hline 1.12 & 1.6 & $0.1 \%$ & $3.06[0.13,70.52]$ \\
\hline & & $100.0 \%$ & $0.82[0.73,0.91]$ \\
\hline
\end{tabular}

D

Study or Subgroup

\begin{tabular}{l} 
Study or Subgroup \\
\hline CANDLE, 2020 \\
EMPA-RESPONSE-AHF, 2019 \\
DECLARE-TIMI 58, 2019 \\
CANVAS, 2017 \\
EMPA-REG OUTCOME, 2015 \\
SOLOIST-WHF, 2020 \\
DAPA-HF, 2019 \\
EMPEROR-Reduced, 2020 \\
CREDENCE, 2019 \\
EMPIRE-HF, 2020 \\
REFORM Trial, 2020 \\
DEFINE-HF, 2019 \\
SUGAR-DM-HF, 2020
\end{tabular}

SUGAR-DM-HF, 2020

Total (95\% Cl) Heterogeneity: $\mathrm{Tau}^{2}=0.00 ; \mathrm{Chi}^{2}=8.12, \mathrm{df}=12(\mathrm{P}=0.78) ; \mathrm{I}^{2}=0 \%$

Heterogeneity: $\mathrm{Tau}^{2}=0.00 ; \mathrm{Ch}^{2}=8.12, \mathrm{df}=12$
Test for overall effect: $\mathrm{Z}=3.97(\mathrm{P}<0.0001)$ $\begin{array}{ccc}\text { Risk Ratio } \\ \text { log[Risk Ratio] } & \text { SE Weight } & \text { IV, Random, 95\% CI }\end{array}$ $\begin{array}{lll}0.1 \% & 0.21[0.01,4.38]\end{array}$ $\begin{array}{llll}-1.11 & 1.08 & 0.2 \% & 0.33[0.04,2.74]\end{array}$ $\begin{array}{llll}-0.53 & 0.2 & 5.9 \% & 0.59[0.40,0.87]\end{array}$ $\begin{array}{llll}-0.36 & 0.16 & 9.2 \% & 0.70[0.51,0.95]\end{array}$ $\begin{array}{llll}-0.24 & 0.21 & 5.3 \% & 0.79[0.52,1.19]\end{array}$ $\begin{array}{llll}-0.2 & 0.17 & 8.1 \% & 0.82[0.59,1.14]\end{array}$ $\begin{array}{llll}-0.19 & 0.08 & 36.6 \% & 0.83[0.71,0.97]\end{array}$ $\begin{array}{lllll}-0.19 & 0.08 & 36.6 \% & 0.83[0.71,0.97] \\ -0.08 & 0.09 & 28.9 \% & 0.92[0.77,1.10]\end{array}$ $\begin{array}{rrrr}-0.08 & 0.09 & 28.9 \% & 0.92[0.77,1.10] \\ -0.07 & 0.21 & 5.3 \% & 0.93[0.62,1.41]\end{array}$ $\begin{array}{rrrr}-0.07 & 0.21 & 5.3 \% & 0.93[0.62,1.41] \\ 0 & 2 & 0.1 \% & 1.00[0.02,50.40]\end{array}$ $\begin{array}{rrrr}0 & 2 & 0.1 \% & 1.00[0.02,50.40] \\ 0 & 1.37 & 0.1 \% & 1.00[0.07,14.66]\end{array}$ $\begin{array}{rrrr}0 & 1.37 & 0.1 \% & 1.00[0.07,14.66] \\ 0.01 & 1.44 & 0.1 \% & 1.01[0.06,16.99]\end{array}$ $\begin{array}{llll}1.12 & 1.6 & 0.1 \% & 3.06[0.13,70.52]\end{array}$ $100.0 \% \quad 0.83[0.75,0.91]$ HHF + CV-MORTALITY Risk Ratio IV, Random, 95\% Cl

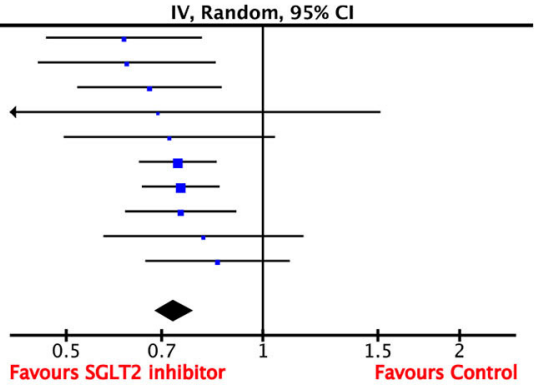

Favours SGLT2 inhibitor $\quad$ Favours Control

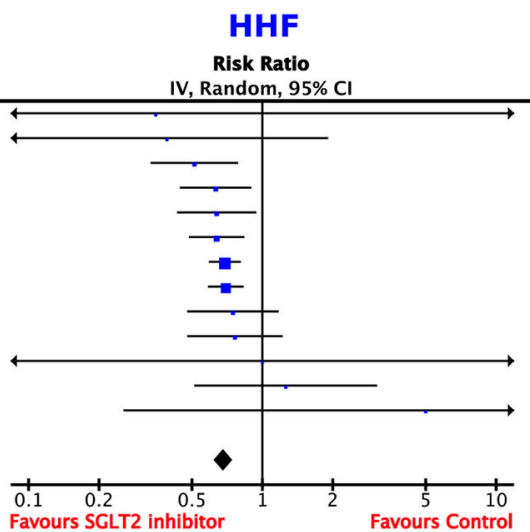

HHF

FIGURE 1 | Forest plot depicting the risk ratio for (A) the composite outcome of hospitalization for heart failure (HHF) or cardiovascular (CV) mortality, (B) HHF alone, (C) CV mortality alone, and (D) all-cause mortality. 
TABLE 2 | Incidence, relative risk reduction (RRR), absolute risk reduction (ARR), and number needed to treat (NNT) for the primary composite endpoint and secondary endpoints.

\begin{tabular}{|c|c|c|c|c|c|c|c|c|}
\hline & Event & $\begin{array}{l}\text { Incidence of } \\
\text { SGLT2 } \\
\text { inhibitor (\%) }\end{array}$ & $\begin{array}{l}\text { Incidence of } \\
\text { comparator } \\
\text { (\%) }\end{array}$ & RRR (\%) & ARR (\%) & NNT & $\begin{array}{l}\text { No. of events reduced } \\
\text { with SGLT2 inhibitors per } \\
1,000 \text { treated patients }\end{array}$ & $p$-value \\
\hline & $\mathrm{HHF}$ & 11 & 16 & 32 & 5 & 20 & 50 & $<0.001$ \\
\hline \multicolumn{9}{|l|}{ Main analyses } \\
\hline Diabetes & Primary composite & 18 & 25 & 28 & 7 & 15 & 70 & $<0.001$ \\
\hline Non-Diabetes & $\begin{array}{l}\text { outcome: } \mathrm{HHF} \text { or } \mathrm{CV} \\
\text { mortality }\end{array}$ & 14 & 18 & 24 & 4 & 25 & 40 & $<0.001$ \\
\hline $\mathrm{HFrEF}(\mathrm{EF} \leq 40 \%)$ & \multirow{3}{*}{$\begin{array}{l}\text { Primary composite } \\
\text { outcome: HHF or CV } \\
\text { mortality }\end{array}$} & 18 & 24 & 25 & 6 & 17 & 60 & $<0.001$ \\
\hline Acute HF & & 40 & 59 & 33 & 18 & 6 & 180 & 0.002 \\
\hline Unknown EF & & 14 & 19 & 26 & 5 & 20 & 50 & $<0.001$ \\
\hline Canagliflozin & \multirow{5}{*}{$\begin{array}{l}\text { Primary composite } \\
\text { outcome: HHF or CV } \\
\text { mortality }\end{array}$} & 14 & 21 & 31 & 7 & 15 & 70 & 0.007 \\
\hline Dapagliflozin & & 15 & 21 & 28 & 6 & 17 & 60 & $<0.001$ \\
\hline Empagliflozin & & 17 & 23 & 26 & 5 & 20 & 50 & $<0.001$ \\
\hline Ertugliflozin & & 12 & 14 & 15 & 2 & 50 & 20 & 0.22 \\
\hline Sotagliflozin & & 40 & 56 & 28 & 16 & 7 & 160 & $<0.001$ \\
\hline Canagliflozin & \multirow[t]{3}{*}{$\mathrm{HHF}$} & 6 & 10 & 39 & 4 & 25 & 40 & 0.002 \\
\hline Dapagliflozin & & 10 & 14 & 30 & 4 & 25 & 40 & $<0.001$ \\
\hline Empagliflozin & & 13 & 17 & 30 & 4 & 25 & 40 & $<0.001$ \\
\hline Dapagliflozin & \multirow{3}{*}{ All-cause mortality } & 11 & 14 & 21 & 3 & 34 & 30 & 0.001 \\
\hline Empagliflozin & & 12 & 13 & 10 & 1 & 100 & 10 & 0.19 \\
\hline Sotagliflozin & & 11 & 13 & 18 & 2 & 50 & 20 & 0.24 \\
\hline \multicolumn{9}{|l|}{ Subgroup analyses } \\
\hline Male & \multirow{12}{*}{$\begin{array}{l}\text { Primary composite } \\
\text { outcome: HHF or CV } \\
\text { mortality }\end{array}$} & 15 & 20 & 26 & 5 & 20 & 50 & $<0.001$ \\
\hline Female & & 11 & 16 & 30 & 5 & 20 & 50 & $<0.001$ \\
\hline Age $<65$ years & & 15 & 20 & 25 & 5 & 20 & 50 & $<0.001$ \\
\hline Age $\geq 65$ years & & 14 & 19 & 28 & 5 & 20 & 50 & $<0.001$ \\
\hline $\mathrm{BMI}<30 \mathrm{~kg} / \mathrm{m}^{2}$ & & 16 & 22 & 26 & 6 & 17 & 60 & $<0.001$ \\
\hline $\mathrm{BMI} \geq 30 \mathrm{~kg} / \mathrm{m}^{2}$ & & 17 & 23 & 27 & 6 & 17 & 60 & $<0.001$ \\
\hline $\begin{array}{l}\text { eGFR 30-60 (ml/min/1.73 } \\
\left.\mathrm{m}^{2}\right)\end{array}$ & & 15 & 20 & 27 & 5 & 20 & 50 & $<0.001$ \\
\hline eGFR $\geq 60\left(\mathrm{ml} / \mathrm{min} / 1.73 \mathrm{~m}^{2}\right)$ & & 13 & 18 & 27 & 5 & 20 & 50 & $<0.001$ \\
\hline Ischemic HF & & 16 & 22 & 27 & 6 & 17 & 60 & 0.001 \\
\hline Non-Ischemic HF & & 15 & 21 & 29 & 6 & 17 & 60 & $<0.001$ \\
\hline Use of MRA & & 15 & 21 & 27 & 6 & 17 & 60 & $<0.001$ \\
\hline No use of MRA & & 14 & 18 & 25 & 4 & 25 & 40 & $<0.001$ \\
\hline
\end{tabular}




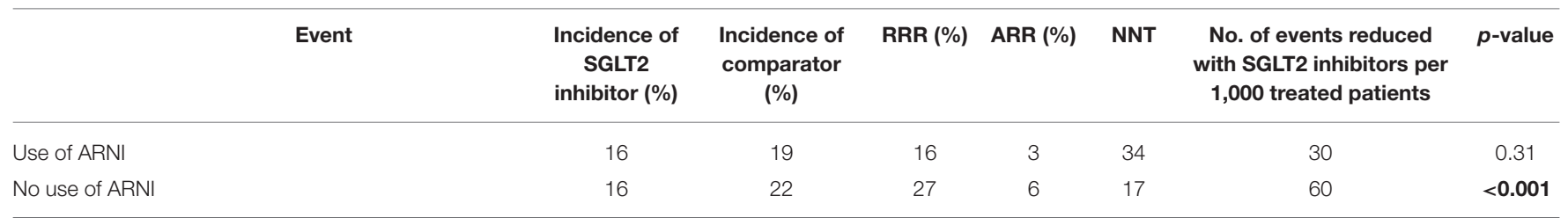

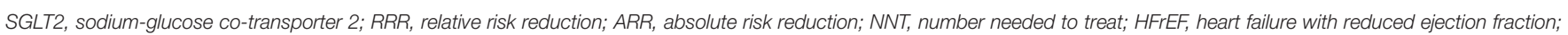

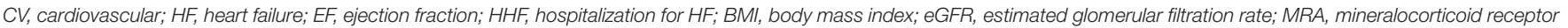
antagonist; ARNI, angiotensin receptor neprilysin inhibitor. Bold values are deemed as statistically significant.

\section{BMI $\left(\mathrm{kg} / \mathrm{m}^{2}\right)$}

The magnitude of the effect for the prevention of HHF or CV mortality was similar in patients with a BMI $<30$ and a BMI $\geq 30$ $\mathrm{kg} / \mathrm{m}^{2}(\mathrm{RRR}=26 \%, \mathrm{RR}=0.74,95 \% \mathrm{CI}=0.66-0.83, p<0.00001$, $I^{2}=0 \% ; \mathrm{RRR}=27 \%, \mathrm{RR}=0.73,95 \% \mathrm{CI}=0.61-0.87, p=0.0007$, $\left.I^{2}=32 \%\right)($ Figure 5C).

\section{eGFR (ml/min/1.73 $\left.\mathrm{m}^{2}\right)$}

The benefit of SGLT2 inhibition was independent of patients' eGFRs, obtaining a RRR of $27 \%$ in both patients with eGFRs of $30-60$ and $\geq 60\left(\mathrm{RR}=0.73,95 \% \mathrm{CI}=0.61-0.86, p=0.0003, I^{2}\right.$ $\left.=49 \% ; \mathrm{RR}=0.73,95 \% \mathrm{CI}=0.64-0.83, p<0.00001, I^{2}=0 \%\right)$ (Figure 6A).

\section{Cause of HF}

Regardless of an ischemic or non-ischemic origin of HF, SGLT2 inhibition reached sufficient effects for the prevention of the composite endpoint. When suffering from ischemic HF, the resulting RRR obtained was $27 \%$, whereas, the RRR was $29 \%$ when a non-ischemic $\mathrm{HF}$ was diagnosed $(\mathrm{RR}=0.73,95 \% \mathrm{CI}=$ $0.60-0.88, p=0.001, I^{2}=63 \% ; \mathrm{RR}=0.71,95 \% \mathrm{CI}=0.62-0.81$, $\left.p<0.00001, I^{2}=0 \%\right)$ (Figure 6B).

\section{Use of Mineralocorticoid Receptor Antagonists}

Concomitant medication with mineralocorticoid receptor antagonists (MRAs) did not modify the beneficial effects of treatment with SGLT2 inhibitors. The use of MRAs was associated with a RRR of $27 \%(\mathrm{RR}=0.73,95 \% \mathrm{CI}=0.66-0.81$, $p<0.00001, I^{2}=0 \%$ ), whereas, renunciation of MRA use obtained a RRR of $25 \%(\mathrm{RR}=0.75,95 \% \mathrm{CI}=0.65-0.87, p<$ $\left.0.00001, I^{2}=0 \%\right)$ (Figure 7A).

\section{Use of Angiotensin Receptor Neprilysin Inhibitors}

In patients under treatment with angiotensin receptor neprilysin inhibitors (ARNIs), the RRR of SGLT2 inhibition was 16\%, which did not reach statistical significance ( $p=0.31$ ). In comparison, SGLT2 inhibitor treatment resulted in a RRR of $27 \%$ in patients who were also treated with ARNIs ( $\mathrm{RR}=0.73,95 \% \mathrm{CI}=$ $\left.0.67-0.80, p<0.00001, I^{2}=0 \%\right)($ Figure $7 \mathrm{~B})$.

\section{Period of Follow-Up ( $\leq 1.5$ and $>1.5$ Years)}

Based on the mean follow-up time of 18 months, we set the cutoff for the subgroup analysis at 1.5 years $(\leq 1.5$ and $>1.5$ years; Supplementary Figure 3$)$. The shorter follow-up period $(\leq 1.5$ years) did not alter the beneficial effects negatively, which were observed under treatment with SGLT2 inhibitors, with a resulting
$\mathrm{RRR}$ of $26 \%\left(\mathrm{RR}=0.74,95 \% \mathrm{CI}=0.68-0.80, p<0.00001, I^{2}=\right.$ $0 \%)$. In comparison, follow-up times longer than 1.5 years were associated with a RRR of $28 \%(\mathrm{RR}=0.72,95 \% \mathrm{CI}=0.62-0.83$, $p<0.00001, I^{2}=8 \%$ ). Set side by side to the overall analysis for the composite endpoint with a RRR of $27 \%$, the effects are of similar magnitude $(\mathrm{RR}=0.73,95 \% \mathrm{CI}=0.68-0.78, p<0.00001$, $\left.I^{2}=0 \%\right)$.

\section{Sensitivity Analysis}

The results of the random and fixed effects were revealed to be similar (data not shown).

Excluding single studies from the analyses did not change the direction and the magnitude of the effect. In patients who were treated with ARNIs, the use of sotagliflozin did not result in a reduction of the primary endpoint, but the use of dapagliflozin or empagliflozin was associated with a reduction of the primary endpoint.

The visual inspection of the funnel plot has shown minor asymmetry (data not shown).

\section{DISCUSSION}

The present meta-analysis investigated various RCTs of SGLT2 inhibitors regarding their clinical outcomes, with a particular focus on a patient population with established HF at baseline. Our results highlight that all SGLT2 inhibitors lower the risk of CV death, all-cause mortality, and $\operatorname{HHF}(1-3,5)$ in patients with underlying HF diagnosis. Hospitalization for HF emerged as the outcome, which was best reduced by SGLT2 inhibitors $(\mathrm{RRR}=32 \%)$.

Previous meta-analyses have already reported on the outstanding ability of different SGLT2 inhibitors in decreasing the rates of hospitalization due to heart failure in participants with or without $\mathrm{HF}$ at baseline $(50,51)$. In our analysis, we put focus on the different types of HF, including HFrEF (EF $\leq 40 \%$ and $\leq 45 \%$ ), HFmrEF (EF $40-50 \%$ ), HFpEF (EF $>45 \%$ and $>50 \%$ ), and acute HF. We also included a subgroup of HF with unknown EF due to the fact that some studies did not classify between the different forms of HF, such as the EMPA-REG OUTCOME, CANVAS, CREDENCE, or VERTIS-CV post-hoc analysis $(44-46,49)$. Furthermore, some studies solely focused on patients with HFrEF [EMPEROR-Reduced (34), DAPA-HF trial (2), and DEFINE-HF trial (39)] or used different left ventricular ejection fraction (LVEF) thresholds to distinguish between HFrEF and HFpEF [DECLARE-TIMI 58 post-hoc analysis, EF 
HHF + CV-MORTALITY

Risk Ratio

Study or Subgroup

log[Risk Ratio] SE Weight IV, Random, $95 \% \mathrm{CI}$

DIABETES
CANVAS, 2017

CANVAS, 2017
DECLARE-TIMI 58, 2019

SOLOIST-WHF, 2020

EMPEROR-Reduced, 2020

EMPA-REC OUTCOME, 2015

DAPA-HF, 2019

SCORED, 2020

CREDENCE, 2019

VERTIS CV, 2020

Subtotal ( $95 \% \mathrm{Cl})$

Heterogeneity: Tau $^{2}=0.00 ; \mathrm{Chi}^{2}=4.95, \mathrm{df}=8(\mathrm{P}=0.76) ; \mathrm{I}^{2}=0 \%$

$\begin{array}{llll}-0.49 & 0.14 & 8.3 \% & 0.61[0.47,0.81]\end{array}$

$\begin{array}{llll}-0.48 & 0.16 & 6.4 \% & 0.62[0.45,0.85]\end{array}$

$\begin{array}{llll}-0.4 & 0.13 & 9.6 \% & 0.67[0.52,0.86]\end{array}$

$\begin{array}{llll}-0.33 & 0.09 & 20.1 \% & 0.72[0.60,0.86]\end{array}$

$\begin{array}{llll}-0.33 & 0.19 & 4.5 \% & 0.72[0.50,1.04]\end{array}$

$\begin{array}{llll}-0.29 & 0.09 & 20.1 \% & 0.75[0.63,0.89]\end{array}$

$\begin{array}{llllll}-0.29 & 0.1 & 16.3 \% & 0.75[0.62 & 0.91]\end{array}$

$\begin{array}{llll}-0.21 & 0.18 & 5.0 \% & 0.81[0.57,1.15]\end{array}$

$\begin{array}{llll}-0.21 & 0.18 & 5.0 \% & 0.81[0.57,1.15] \\ -0.16 & 0.13 & 9.6 \% & 0.85[0.66,1.10]\end{array}$ $0.85[0.66,1.10]$
$0.72[0.67,0.78]$ (1)

\section{NON-DIABETES}

EMPEROR-Reduced, 2020

Subtotal $(95 \% \mathrm{Cl})$

$\begin{array}{lll}-0.31 & 0.1 & 50.0 \%\end{array}$

$\begin{array}{lll}-0.25 & 0.1 \quad 50.0 \%\end{array}$ $100.0 \%$

Heterogeneity: $\mathrm{Tau}^{2}=0.00 ; \mathrm{Chi}^{2}=0.18, \mathrm{df}=1(\mathrm{P}=0.67) ; \mathrm{I}^{2}=0 \%$

Test for overall effect: $Z=3.96(P<0.0001)$

Test for subgroup differences: $\mathrm{Chi}^{2}=0.27, \mathrm{df}=1(\mathrm{P}=0.60), \mathrm{I}^{2}=0 \%$

$0.73[0.60,0.89]$ $0.78[0.64,0.95]$ $0.76[0.66,0.87]$

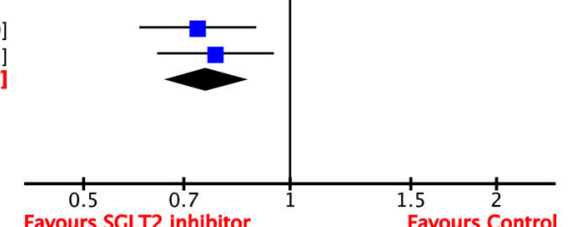

Favours SGLT2 inhibitor

HHF + CV-MORTALITY

B

Risk Ratio

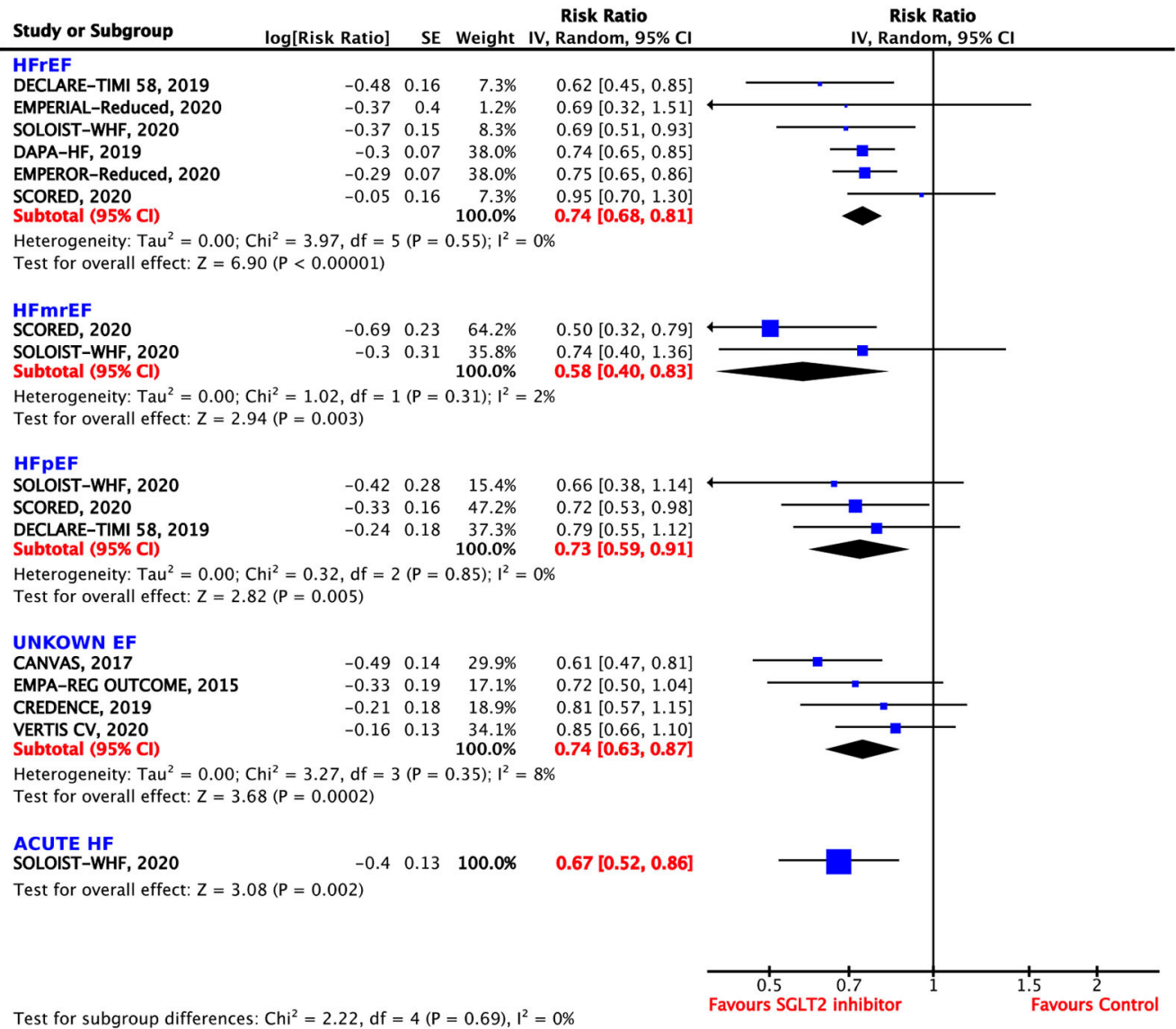

FIGURE 2 | Forest plot depicting the relative risk (RR) for the composite outcome of hospitalization for heart failure (HHF) or cardiovascular (CV) mortality in (A) patients with or without diabetes and (B) depending on the type of heart failure (HF): HFrEF (HF with reduced ejection fraction), HFmrEF (HF with mid-range ejection fraction), $\mathrm{HFpEF}$ (HF with preserved ejection fraction), unknown EF, and acute HF. 
A

Study or Subgroup

CANAGLIFLOZIN

CANVAS, 2017

CREDENCE, 2019

$\begin{array}{lll}\text { Subtotal }(95 \% \mathrm{Cl}) & 100.0 \% & 0.69[0.53,0.90]\end{array}$

Heterogeneity: $\mathrm{Tau}^{2}=0.01 ; \mathrm{Chi}^{2}=1.51, \mathrm{df}=1(\mathrm{P}=0.22) ; \mathrm{I}^{2}=34 \%$

Test for overall effect: $Z=2.70(P=0.007)$

DAPAGLIFLOZIN

DECLARE-TIMI 58, 2019

DAPA-HF, 2019

Subtotal $(95 \% \mathrm{Cl})$

Test for overall effect: $Z=4.80(P<0.00001)$

EMPAGLIFLOZIN

EMPERIAL-Reduced, 2020

EMPA-REG OUTCOME, 2015

EMPEROR-Reduced, 2020

Subtotal (95\% CI)

Heterogeneity: $\mathrm{Tau}^{2}=0.00 ; \mathrm{Chi}^{2}=0.07, \mathrm{df}=2(\mathrm{P}=0.96) ; \mathrm{I}^{2}=0 \%$

Test for overall effect: $Z=4.58(P<0.00001)$

\section{ERTUGLIFLOZIN \\ VERTIS CV, 2020}

Test for overall effect: $Z=1.23(P=0.22)$

$\begin{array}{lll}-0.16 & 0.13 \quad 100.0 \%\end{array}$

$0.85[0.66,1.10]$

SOTAGLIFLOZIN

SOLOIST-WHF, 2020

SCORED, 2020

Subtotal $(95 \% \mathrm{Cl})$

Heterogeneity: $\operatorname{Tau}^{2}=0.00 ; \mathrm{Chi}^{2}=0.45, \mathrm{df}=1(\mathrm{P}=0.50) ; I^{2}=0 \%$
Test for overall effect: $Z=4.17(\mathrm{P}<0.0001)$

Test for subgroup differences: $\mathrm{Chi}^{2}=1.75, \mathrm{df}=4(\mathrm{P}=0.78), \mathrm{I}^{2}=0 \%$ $\begin{array}{rrrr}-0.4 & 0.13 & 37.2 \% & 0.67[0.52,0.86] \\ -0.29 & 0.1 & 62.8 \% & 0.75[0.62,0.91] \\ & & 100.0 \% & \mathbf{0 . 7 2}[0.61,0.84]\end{array}$ $0.72[0.61,0.84]$

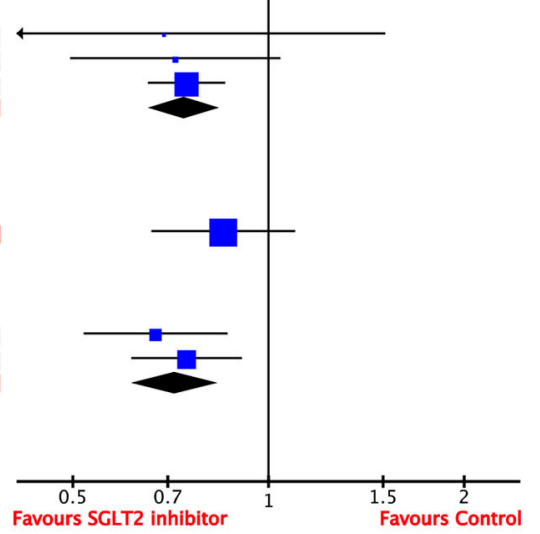

HHF + CV-MORTALITY

Risk Ratio IV, Random, 95\% CI

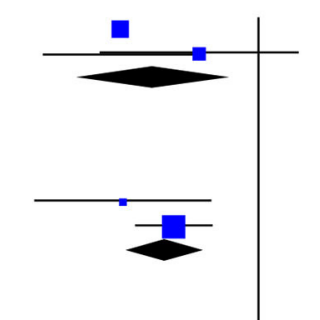

B

\begin{tabular}{|c|c|c|c|c|}
\hline Study or Subgroup & log[Risk Ratio] & SE & Weight & $\begin{array}{l}\text { Risk Ratio } \\
\text { IV, Random, } 95 \% \mathrm{CI}\end{array}$ \\
\hline \multicolumn{5}{|l|}{$\begin{array}{l}\text { CANAGLIFLOZIN } \\
\text { CANDLE, } 2020\end{array}$} \\
\hline CANVAS, 2017 & -0.67 & 0.22 & $53.9 \%$ & $0.51[0.33,0.79]$ \\
\hline $\begin{array}{l}\text { CREDENCE, } 2019 \\
\text { Subtotal }(95 \% \mathrm{Cl})\end{array}$ & -0.27 & 0.24 & $\begin{array}{r}45.3 \% \\
100.0 \%\end{array}$ & $\begin{array}{l}0.76[0.48,1.22] \\
0.61[0.45,0.84]\end{array}$ \\
\hline \multicolumn{5}{|c|}{$\begin{array}{l}\text { Heterogeneity: } \text { Tau }^{2}=0.00 ; \mathrm{Chi}^{2}=1.61, \mathrm{df}=2(\mathrm{P}=0.45) ; \mathrm{I}^{2}=0 \% \\
\text { Test for overall effect: } \mathrm{Z}=3.04(\mathrm{P}=0.002)\end{array}$} \\
\hline \multicolumn{5}{|l|}{ DAPAGLIFLOZIN } \\
\hline DECLARE-TIMI 58, 2019 & -0.45 & 0.2 & $16.3 \%$ & $0.64[0.43,0.94]$ \\
\hline DAPA-HF, 2019 & -0.36 & 0.09 & $80.3 \%$ & $0.70[0.58,0.83]$ \\
\hline REFORM Trial, 2020 & 0 & 1.36 & $0.4 \%$ & $1.00[0.07,14.38]$ \\
\hline $\begin{array}{l}\text { DEFINE-HF, } 2019 \\
\text { Subtotal }(95 \% \mathrm{Cl})\end{array}$ & 0.23 & 0.46 & $\begin{array}{r}3.1 \% \\
100.0 \%\end{array}$ & $\begin{array}{l}1.26[0.51,3.10] \\
0.70[0.60,0.82]\end{array}$ \\
\hline \multicolumn{5}{|c|}{$\begin{array}{l}\text { Heterogeneity: } \mathrm{Tau}^{2}=0.00 ; \mathrm{Chi}^{2}=1.91, \mathrm{df}=3(P=0.59) ; \mathrm{I}^{2}=0 \% \\
\text { Test for overall effect: } Z=4.40(P<0.0001)\end{array}$} \\
\hline \multicolumn{5}{|l|}{ EMPAGLIFLOZIN } \\
\hline EMPA-RESPONSE-AHF, 2019 & -0.94 & 0.81 & $0.9 \%$ & $0.39[0.08,1.91]$ \\
\hline EMPEROR-Reduced, 2020 & -0.37 & 0.08 & $88.2 \%$ & $0.69[0.59,0.81]$ \\
\hline EMPA-REG OUTCOME, 2015 & -0.29 & 0.23 & $10.7 \%$ & $0.75[0.48,1.17]$ \\
\hline $\begin{array}{l}\text { RECEDE-CHF, } 2020 \\
\text { Subtotal }(95 \% \mathrm{Cl})\end{array}$ & 1.61 & 1.52 & $\begin{array}{r}0.2 \% \\
100.0 \%\end{array}$ & $\begin{array}{r}5.00[0.25,98.41] \\
0.70[0.60,0.81]\end{array}$ \\
\hline \multicolumn{5}{|c|}{$\begin{array}{l}\text { Heterogeneity: } \mathrm{Tau}^{2}=0.00 ; \mathrm{Chi}^{2}=2.30, \mathrm{df}=3(\mathrm{P}=0.51) ; \mathrm{I}^{2}=0 \% \\
\text { Test for overall effect: } Z=4.81(\mathrm{P}<0.00001)\end{array}$} \\
\hline \multicolumn{5}{|l|}{ ERTUGLIFLOZIN } \\
\hline \multicolumn{5}{|c|}{ Test for overall effect: $Z=2.56(P=0.01)$} \\
\hline $\begin{array}{l}\text { SOTAGLIFLOZIN } \\
\text { SOLOIST-WHF, } 2020\end{array}$ & -0.45 & 0.14 & $100.0 \%$ & $0.64[0.48,0.84]$ \\
\hline \multicolumn{5}{|c|}{ Test for overall effect: $Z=3.21(P=0.001)$} \\
\hline
\end{tabular}

FIGURE 3 | Forest plot depicting the relative risk (RR) according to the administered type of sodium-glucose co-transporter 2 (SGLT2) inhibitor for (A) the composite outcome of hospitalization for heart failure (HHF) or cardiovascular (CV) mortality and (B) HHF alone. 
A

Study or Subgroup

CANAGLIFLOZIN

CANVAS, 2017

Test for overall effect: $Z=1.83(P=0.07)$

DAPAGLIFLOZIN
REFORM Trial, 2020

DECLARE-TIMI 58, 2019

DAPA-HF, 2019

DEFINE-HF, 2019

Subtotal (95\% Cl)

Heterogeneity: $\mathrm{Tau}^{2}=0.03 ; \mathrm{Chi}^{2}=3.92, \mathrm{df}=3(\mathrm{P}=0.27) ; \mathrm{I}^{2}=24 \%$

Test for overall effect: $Z=2.07(P=0.04)$

EMPAGLIFLOZIN

EMPA-REG OUTCOME, 2015

EMPEROR-Reduced, 2020

EMPIRE-HF, 2020

SUGAR-DM-HF, 2020

Subtotal (95\% Cl)

Test for overall effect: $Z=1.17(P=0.24)$

\section{SOTAGLIFLOZIN}

SOLOIST-WHF, 2020

Test for overall effect: $Z=0.89(P=0.37) j$

$\begin{array}{llll}-0.17 & 0.19 & 100.0 \% & 0.84[0.58,1.22]\end{array}$

Risk Ratio

$\begin{array}{llll}-0.33 & 0.18 & 100.0 \% & 0.72[0.51,1.02]\end{array}$

$\begin{array}{rrr}-1.97 & 1.35 & 1.4 \% \\ -0.6 & 0.25 & 28.6 \%\end{array}$

$\begin{array}{lll}-0.2 & 0.09 & 68.7 \%\end{array}$

$\begin{array}{rrr}0.01 & 1.44 & 1.3 \% \\ & & 100.0 \%\end{array}$

$0.14[0.01,1.97]$

$0.55[0.34,0.90]$

$0.82[0.69,0.98]$

$1.01[0.06,16.99]$
$0.71[0.52,0.98]$

$4 \%$

$\begin{array}{rrrr}-0.34 & 0.26 & 12.8 \% & 0.71[0.43,1.18] \\ -0.08 & 0.1 & 86.6 \% & 0.92[0.76,1.12]\end{array}$

$\begin{array}{llll}-0.08 & 0.1 & 86.6 \% & 0.92[0.76,1.12]\end{array}$

$\begin{array}{llll}0 & 2 & 0.2 \% & 1.00[0.02,50.40]\end{array}$

$\begin{array}{llll}1.12 & 1.6 & 0.3 \% & 3.06\end{array}[0.13,70.52]$

$3.06[0.90[0.75,1.08]$
0

df $=3(P=0.69) ; I^{2}=0 \%$

Test for subgroup differences: $\mathrm{Chi}^{2}=2.18, \mathrm{df}=3(\mathrm{P}=0.53), \mathrm{I}^{2}=0 \%$

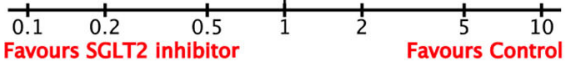

B

Study or Subgroup

Risk Ratio

CANAGLIFLOZIN

CANDLE, 2020

CANVAS, 2017

CREDENCE, 2019

Subtotal $(95 \% \mathrm{Cl})$

Heterogeneity: $\mathrm{Tau}^{2}=0.00 \cdot \mathrm{Chi}^{2}=1.91, \mathrm{df}=2(\mathrm{P}=0.38) \cdot \mathrm{l}^{2}=0 \%$

Test for overall effect: $Z=2.07(P=0.04)$

$\begin{array}{rrrr}-1.56 & 1.55 & 0.7 \% & 0.21[0.01,4.38] \\ -0.36 & 0.16 & 62.8 \% & 0.70[0.51,0.95] \\ -0.07 & 0.21 & 36.5 \% & 0.93[0.62,1.41] \\ & & \mathbf{1 0 0 . 0 \%} & \mathbf{0 . 7 7}[0.60,0.99]\end{array}$

Risk Ratio
Random, $95 \% \mathrm{Cl}$

ALL-CAUSE MORTALITY

Risk Ratio

IV, Random, $95 \% \mathrm{Cl}$

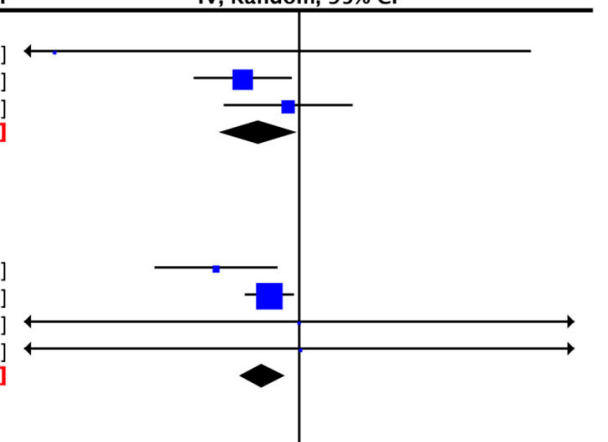

DAPAGLIFLOZIN

DECLARE-TIMI 58, 2019

DAPA-HF, 2019

REFORM Trial, 2020

DEFINE-HF, 2019

$\begin{array}{rrr}-0.53 & 0.2 & 13.7 \% \\ -0.19 & 0.08 & 85.7 \% \\ 0 & 1.37 & 0.3 \% \\ 0.01 & 1.44 & 0.3 \%\end{array}$

$100.0 \%$
Heterogeneity: $\mathrm{Tau}^{2}=0.00 ; \mathrm{Chi}^{2}=2.55, \mathrm{df}=3(\mathrm{P}=0.47) ; \mathrm{I}^{2}=0 \%$

Test for overall effect: $Z=3.18(P=0.001)$
CV-MORTALITY

Risk Ratio

IV, Random, $95 \% \mathrm{Cl}$

EMPAGLIFLOZIN

EMPA-RESPONSE-AHF, 2019

EMPA-REG OUTCOME, 2015

EMPEROR-Reduced, 2020

EMPIRE-HF, 2020

SUGAR-DM-HF, 2020

Subtotal $(95 \% \mathrm{Cl})$

Heterogeneity: $\mathrm{Tau}^{2}=0.00 ; \mathrm{Chi}^{2}=1.93$, df $=4(P=0.75$

Test for overall effect: $Z=1.30(P=0.19)$

SOTAGLIFLOZIN

SOLOIST-WHF, 2020

$\begin{array}{llll}-0.2 & 0.17 & 100.0 \% & 0.82\end{array}[0.59,1.14]$

Test for overall effect: $Z=1.18(P=0.24)$

$\begin{array}{rrr}-1.11 & 1.08 & 0.6 \% \\ -0.24 & 0.21 & 15.4 \% \\ -0.08 & 0.09 & 83.6 \% \\ 0 & 2 & 0.2 \% \\ 1.1 & 1.6 & 0.3 \% \\ & & 100.0 \%\end{array}$

$d f=4(P=0.75) ; I^{2}=0 \%$ 


\section{Subgroup analyses: HHF + CV-MORTALITY}

A

\begin{tabular}{|c|c|c|c|c|}
\hline Study or Subgroup & log[Risk Ratio] & SE & Weight & $\begin{array}{c}\text { Risk Ratio } \\
\text { IV, Random, 95\% Cl } \\
\end{array}$ \\
\hline \multicolumn{5}{|l|}{ MALE } \\
\hline SOLOIST-WHF, 2020 & -0.48 & 0.14 & $17.2 \%$ & $0.62[0.47,0.81]$ \\
\hline DAPA-HF, 2019 & -0.31 & 0.08 & $41.4 \%$ & $0.73[0.63,0.86]$ \\
\hline $\begin{array}{l}\text { EMPEROR-Reduced, } 2020 \\
\text { Subtotal }(95 \% \mathrm{Cl})\end{array}$ & -0.22 & 0.08 & $\begin{array}{r}41.4 \% \\
100.0 \%\end{array}$ & $\begin{array}{l}0.80[0.69,0.94] \\
0.74[0.65,0.84]\end{array}$ \\
\hline \multicolumn{5}{|c|}{$\begin{array}{l}\text { Heterogeneity: } \mathrm{Tau}^{2}=0.00 ; \mathrm{Chi}^{2}=2.66, \mathrm{df}=2(\mathrm{P}=0.26) ; \mathrm{I}^{2}=25 \% \\
\text { Test for overall effect: } \mathrm{Z}=4.85(\mathrm{P}<0.00001)\end{array}$} \\
\hline \multicolumn{5}{|l|}{ FEMALE } \\
\hline EMPEROR-Reduced, 2020 & -0.53 & 0.15 & $40.5 \%$ & $0.59[0.44,0.79]$ \\
\hline DAPA-HF, 2019 & -0.24 & 0.15 & $40.5 \%$ & $0.79[0.59,1.06]$ \\
\hline $\begin{array}{l}\text { SOLOIST-WHF, } 2020 \\
\text { Subtotal ( } 95 \% \mathrm{CI})\end{array}$ & -0.22 & 0.23 & $\begin{array}{r}19.0 \% \\
100.0 \%\end{array}$ & $\begin{array}{l}0.80[0.51,1.26] \\
\mathbf{0 . 7 0}[\mathbf{0 . 5 7}, \mathbf{0 . 8 6}]\end{array}$ \\
\hline \multicolumn{5}{|c|}{ Heterogeneity: $\mathrm{Tau}^{2}=0.00 ; \mathrm{Chi}^{2}=2.29, \mathrm{df}=2(\mathrm{P}=0.32) ; \mathrm{I}^{2}=13 \%$} \\
\hline
\end{tabular}

Test for subgroup differences: $\mathrm{Chi}^{2}=0.18, \mathrm{df}=1(\mathrm{P}=0.67), \mathrm{I}^{2}=0 \%$

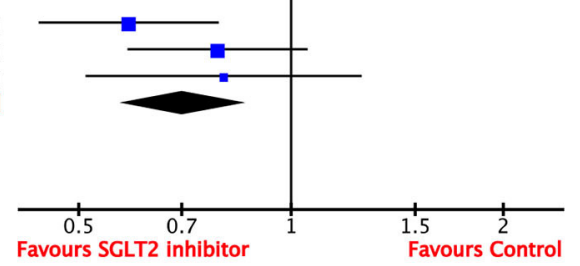

B

Risk Ratio

Study or Subgroup log[Risk Ratio] SE Weight IV, Random, 95\% CI

$<65$ years

EMPEROR-Reduced, 2020

DAPA-HF, 2019

SOLOIST-WHF, 2020

Subtotal (95\% CI)
$\begin{array}{lll}-0.34 & 0.11 & 44.4 \%\end{array}$
$\begin{array}{lll}-0.25 & 0.11 & 44.4 \%\end{array}$
$\begin{array}{lll}-0.24 & 0.22 \quad 11.1 \%\end{array}$
$0.71[0.57,0.88]$
$0.78[0.63,0.97]$
$0.79[0.51,1.21]$

$0.75[0.65,0.86]$

Heterogeneity: $\mathrm{Tau}^{2}=0.00 ; \mathrm{Chi}^{2}=0.39, \mathrm{df}=2(\mathrm{P}=0.82) ; \mathrm{I}^{2}=0 \%$

Test for overall effect: $Z=3.94(P<0.0001)$

$\geq 65$ years

SOLOIST-WHF, 2020

DAPA-HF, 2019

EMPEROR-Reduced, 2020

Subtotal (95\% Cl)

$\begin{array}{lll} & & \\ -0.48 & 0.14 & 17.1 \% \\ -0.33 & 0.09 & 41.4 \% \\ -0.25 & 0.09 & 41.4 \%\end{array}$

$0.78[0.65,0.93]$

作 ${ }^{2}=1.92, \mathrm{df}=2(\mathrm{P}=0.38) ; \mathrm{I}^{2}=0 \%$

Test for overall effect: $Z=5.57(P<0.00001)$

Test for subgroup differences: $\mathrm{Chi}^{2}=0.13, \mathrm{df}=1(\mathrm{P}=0.72), \mathrm{I}^{2}=0 \%$

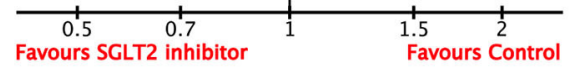

C

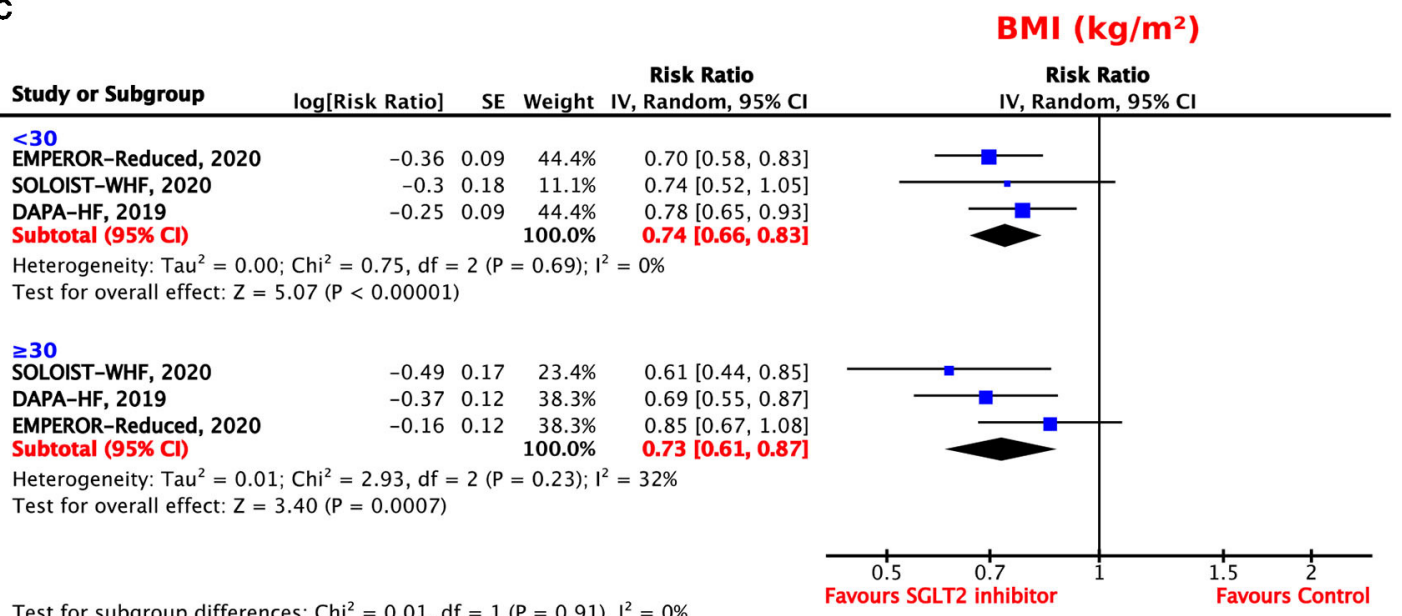

Test for subgroup differences: $\mathrm{Chi}^{2}=0.01, \mathrm{df}=1(\mathrm{P}=0.91), \mathrm{I}^{2}=0 \%$

FIGURE 5 | Subgroup analyses for the composite outcome according to (A) sex, (B) age, and (C) body mass index. 


\section{Subgroup analyes: HHF + CV-MORTALITY}

A

\begin{tabular}{|c|c|c|c|c|}
\hline Study or Subgroup & log[Risk Ratio] & SE & Weight & $\begin{array}{l}\text { Risk Ratio } \\
\text { IV, Random, } 95 \% \mathrm{CI}\end{array}$ \\
\hline \multicolumn{5}{|l|}{$30-60$} \\
\hline DAPA-HF, 2019 & -0.33 & 0.1 & $36.6 \%$ & $0.72[0.59,0.87]$ \\
\hline $\begin{array}{l}\text { EMPEROR-Reduced, } 2020 \\
\text { Subtotal }(95 \% \mathrm{Cl})\end{array}$ & -0.19 & 0.09 & $\begin{array}{r}40.2 \% \\
100.0 \%\end{array}$ & $\begin{array}{l}0.83[0.69,0.99] \\
0.73[0.61,0.86]\end{array}$ \\
\hline \multicolumn{5}{|c|}{$\begin{array}{l}\text { Heterogeneity: } \mathrm{Tau}^{2}=0.01 ; \mathrm{Chi}^{2}=3.93, \mathrm{df}=2(\mathrm{P}=0.14) ; \mathrm{I}^{2}=49 \% \\
\text { Test for overall effect: } \mathrm{Z}=3.60(\mathrm{P}=0.0003)\end{array}$} \\
\hline \multicolumn{5}{|l|}{$\geq 60$} \\
\hline EMPEROR-Reduc & -0.4 & 0.1 & $45.3 \%$ & $0.67[0.55,0.82]$ \\
\hline DAPA-HF, 2019 & -0.27 & 0.1 & $45.3 \%$ & $0.76[0.63,0.93]$ \\
\hline $\begin{array}{l}\text { SOLOIST-WHF, } 2020 \\
\text { Subtotal }(95 \% \mathrm{Cl})\end{array}$ & -0.11 & 0.22 & $\begin{array}{r}9.4 \% \\
100.0 \%\end{array}$ & $\begin{array}{l}0.90[0.58,1.38] \\
\mathbf{0 . 7 3}[0.64,0.83]\end{array}$ \\
\hline
\end{tabular}

Test for subgroup differences: $\mathrm{Chi}^{2}=0.00, \mathrm{df}=1(\mathrm{P}=0.96), \mathrm{I}^{2}=0 \%$
eGFR $\left(\mathrm{ml} / \mathrm{min} / 1.73 \mathrm{~m}^{2}\right)$

Risk Ratio

IV, Random, $95 \% \mathrm{CI}$

B

\section{CAUSE OF HF}

Risk Ratio log[Risk Ratio] SE Weight IV, Random, 95\% Cl

Risk Ratio

Study or Subgroup IV, Random, $95 \% \mathrm{CI}$

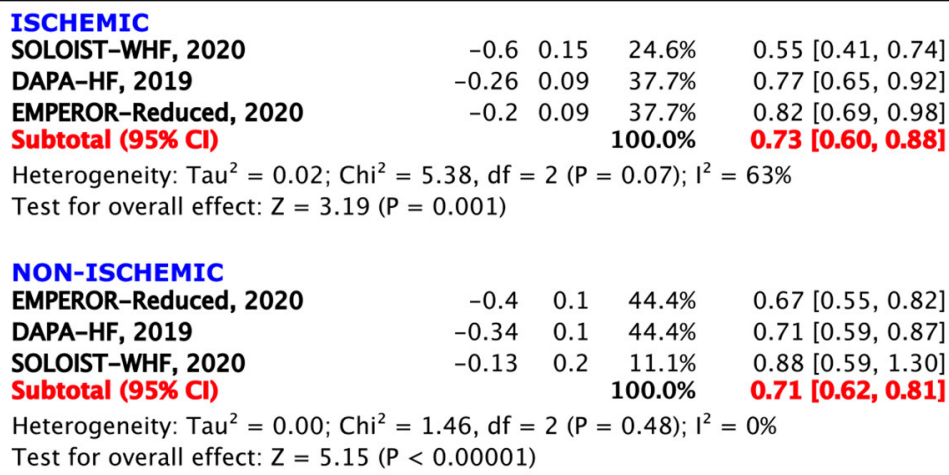

Test for subgroup differences: $\mathrm{Chi}^{2}=0.03, \mathrm{df}=1(\mathrm{P}=0.85), \mathrm{I}^{2}=0 \%$

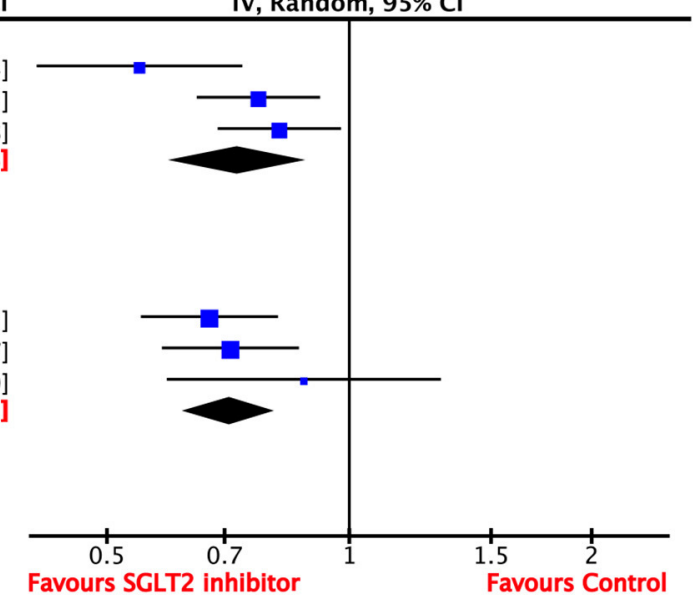

FIGURE 6 | Subgroup analyses for the composite outcome according to the (A) estimated glomerular filtration rate (eGFR) and (B) cause of HF.

$<45 \%$ (43); CANDLE, SOLOIST WHF, and SCORED trial, $\mathrm{EF}<50 \%(6,8,41)]$. In addition, the CANDLE trial did not assess the clinical safety endpoints with regard to the baseline LVEF (41). The reduction of HHF or CV mortality was of similar magnitude in most groups. Interestingly, our analysis show that SGLT2 inhibitors are also effective in HFmrEF and HFpEF, which is a novel finding as there is currently no effective therapy in this patient population. Nevertheless, the majority of the data for the HFmrEF and HFpEF groups were based on trials using sotagliflozin. Therefore, the question remains as to whether SGLT2 inhibitors display a class effect in this unique patient population.

The standard treatment approach for HFrEF currently includes angiotensin-converting enzyme (ACE) inhibitors, MRAs, and beta-blockers. ARNIs, If-channel inhibitors, and diuretics are also often administered in HFrEF. To date, no 


\section{Subgroup analyses: HHF + CV-MORTALITY}

A

\begin{tabular}{|c|c|c|c|c|}
\hline Study or Subgroup & log[Risk Ratio] & SE & Weight & $\begin{array}{c}\text { Risk Ratio } \\
\text { IV, Random, } 95 \% \mathrm{CI} \\
\end{array}$ \\
\hline \multicolumn{5}{|l|}{ YES } \\
\hline SOLOIST-WHF, 2020 & -0.49 & 0.16 & $11.2 \%$ & $0.61[0.45,0.84]$ \\
\hline DAPA-HF, 2019 & -0.3 & 0.08 & $44.7 \%$ & $0.74[0.63,0.87]$ \\
\hline EMPEROR-Reduced, 2020 & -0.29 & 0.09 & $35.3 \%$ & $0.75[0.63,0.89]$ \\
\hline $\begin{array}{l}\text { SCORED, } 2020 \\
\text { Subtotal }(95 \% \mathrm{Cl})\end{array}$ & -0.24 & 0.18 & $\begin{array}{r}8.8 \% \\
100.0 \%\end{array}$ & $\begin{array}{l}0.79[0.55,1.12] \\
\mathbf{0 . 7 3}[\mathbf{0 . 6 6}, \mathbf{0 . 8 1}]\end{array}$ \\
\hline \multicolumn{5}{|c|}{$\begin{array}{l}\text { Heterogeneity: } \text { Tau }^{2}=0.00 ; \mathrm{Chi}^{2}=1.48, \mathrm{df}=3(\mathrm{P}=0.69) ; \mathrm{I}^{2}=0 \% \\
\text { Test for overall effect: } Z=5.84(\mathrm{P}<0.00001)\end{array}$} \\
\hline \multicolumn{5}{|l|}{ NO } \\
\hline DAPA-HF, 2019 & -0.3 & 0.13 & $31.1 \%$ & $0.74[0.57,0.96]$ \\
\hline SCORED, 2020 & -0.3 & 0.15 & $23.3 \%$ & $0.74[0.55,0.99]$ \\
\hline EMPEROR-Reduced, 2020 & -0.27 & 0.13 & $31.1 \%$ & $0.76[0.59,0.98]$ \\
\hline $\begin{array}{l}\text { SOLOIST-WHF, } 2020 \\
\text { Subtotal }(95 \% \mathrm{CI})\end{array}$ & -0.24 & 0.19 & $\begin{array}{r}14.5 \% \\
100.0 \%\end{array}$ & $\begin{array}{l}0.79[0.54,1.14] \\
0.75[0.65,0.87]\end{array}$ \\
\hline \multicolumn{5}{|c|}{ Heterogeneity: $\mathrm{Tau}^{2}=0.00 ; \mathrm{Chi}^{2}=0.09, \mathrm{df}=3(\mathrm{P}=0.99) ; \mathrm{I}^{2}=0 \%$} \\
\hline
\end{tabular}

Test for subgroup differences: $\mathrm{Chi}^{2}=0.11, \mathrm{df}=1(\mathrm{P}=0.74), \mathrm{I}^{2}=0 \%$

\section{MRA USE}

Risk Ratio IV, Random, $95 \% \mathrm{CI}$

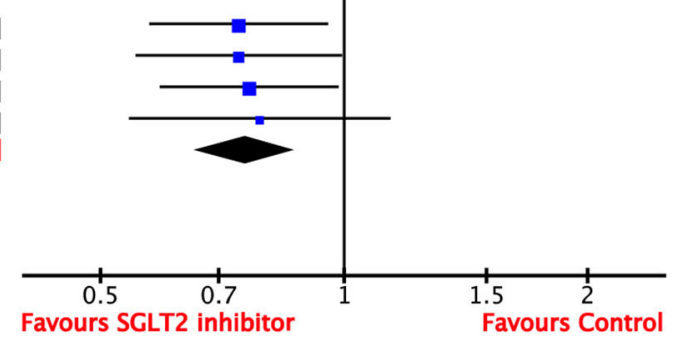

B

\section{ARNi USE}

Risk Ratio log[Risk Ratio] SE Weight IV, Random, 95\% CI

Risk Ratio

IV, Random, $95 \% \mathrm{Cl}$

\footnotetext{
YES EMPEROR-Reduced, 2020

DAPA-HF, 2019

SOLOIST-WHF, 2020

SCORED, 2020

Subtotal $(95 \% \mathrm{Cl})$

$\begin{array}{rrrr}-0.45 & 0.18 & 34.4 \% & 0.64[0.45,0.91] \\ -0.29 & 0.21 & 30.2 \% & 0.75[0.50,1.13] \\ 0.03 & 0.29 & 21.3 \% & 1.03[0.58,1.82] \\ 0.46 & 0.39 & 14.1 \% & 1.58[0.74,3.40] \\ & & \mathbf{1 0 0 . 0 \%} & \mathbf{0 . 8 4}[\mathbf{0 . 6 0}, \mathbf{1 . 1 7}]\end{array}$

Heterogeneity: $\mathrm{Tau}^{2}=0.05 ; \mathrm{Chi}^{2}=5.51, \mathrm{df}=3(\mathrm{P}=0.14) ; \mathrm{I}^{2}=46 \%$

Test for overall effect: $Z=1.01(P=0.31)$

NO

SOLOIST-WHF, 2020

SCORED, 2020

DAPA-HF, 2019

EMPEROR-Reduced, 2020

Subtotal $(95 \% \mathrm{Cl})$

Heterogeneity: $\mathrm{Tau}^{2}=0.00 ; \mathrm{Chi}^{2}=2.33, \mathrm{df}=3(\mathrm{P}=0.51) ; \mathrm{I}^{2}=0 \%$

$\begin{array}{lll}-0.49 & 0.13 & 12.1 \%\end{array}$

$\begin{array}{lll}-0.31 & 0.12 & 14.2 \%\end{array}$

$\begin{array}{lll}-0.3 & 0.07 & 41.7 \%\end{array}$

$\begin{array}{lll}-0.26 & 0.08 \quad 32.0 \%\end{array}$ $\begin{array}{rr}32.0 \% & 0.77[0.66,0.90] \\ 100.0 \% & 0.73[0.67,0.80]\end{array}$

$0.61[0.47,0.79]$ $0.73[0.58,0.93]$ $0.74[0.65,0.85]$ Test for overall effect: $Z=6.89(P<0.00001)$
}

Test for subgroup differences: $\mathrm{Chi}^{2}=0.64, \mathrm{df}=1(\mathrm{P}=0.42), \mathrm{I}^{2}=0 \%$

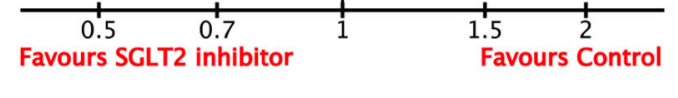

FIGURE 7 | Subgroup analyses for the composite outcome according to concomitant use of (A) mineralocorticoid receptor antagonists (MRAs) and (B) angiotensin receptor neprilysin inhibitors (ARNIs).

pharmacotherapy ameliorating the prognosis in patients with HFpEF has been proven; therefore, treatment of the symptoms and comorbidities is the current approach (52-54). Although, some data indicate SGLT2 inhibitors as a sufficient therapy option for patients with HFpEF, results of large outcome trials, which investigate particularly participants with HFpEF, such as 
the EMPEROR-Preserved trial (Empagliflozin Outcome Trial in Patients with Chronic Heart Failure with Preserved Ejection Fraction; NCT03057951) or the DELIVER trial (Dapagliflozin Evaluation to Improve the Lives of Patients with Preserved Ejection Fraction Heart Failure; NCT03619213), are ultimately required to confirm these assumptions $(55,56)$.

Heart failure is highly associated with comorbidities, which directly affect patients' mortality and morbidity. A survey from 2014 demonstrated that $74 \%$ of 3,226 patients with chronic HF suffer at least from one comorbidity, the most frequent being chronic kidney disease, anemia, and diabetes (57). The link between $\mathrm{HF}$ and diabetes has been reported previously (58), making medication treating both conditions even more appealing. Interestingly, a post-hoc analysis of the DAPA-HF trial (2) showed that dapagliflozin acted comparably efficiently in reducing the composite endpoint in individuals with or without diabetes $(\mathrm{HR}=0.75$ vs. $0.73, p$-value for interaction $=0.83$ ). According to these results, one can assume that dapagliflozin is applicable to patients with HFrEF, irrespective of their glycemic status (34). Of note is that dapagliflozin indeed reduced the glycated hemoglobin (HbAlc) in people with diabetes; however, it had no effect on HbAlc in patients without diagnosed diabetes (47). The safety and tolerability of dapagliflozin in people without diabetes were also suggested in the DEFINE-HF trial; nevertheless, this study was not powered for clinical outcomes, including a small sample size of only 263 patients (63\% of which had T2DM) and a short followup period of only 12 weeks (39). The very recent EMPERORReduced trial also demonstrated a similar efficacy in reducing the composite endpoints of CV mortality and HHF in the diabetic and non-diabetic subpopulations ( $\mathrm{HR}=0.72$ vs. 0.78 ), leading to the assumption that empagliflozin is also beneficial in people with HFrEF independent of the presence of diabetes (34). Our meta-analysis further confirmed the similar efficacy profiles of canagliflozin, dapagliflozin, empagliflozin, and sotagliflozin for their composite endpoint, regardless of the diabetes status.

Cardiovascular mortality and all-cause mortality were also reduced in patients who were administered SGLT2 inhibitors as compared to the control group, with a RRR of $17-18 \%$. Interestingly, when analyzed with regard to the type of SGLT2 inhibitor used (empagliflozin, dapagliflozin, canagliflozin, and sotagliflozin), the magnitude of the effect varied, which might be due to the differences in the studied populations. Interestingly, dapagliflozin reduced $\mathrm{CV}$ mortality in our meta-analysis in HF patients significantly, whereas, empagliflozin, canagliflozin, and sotagliflozin did not reach statistical significance. Importantly, a recent meta-analysis that investigated SGLT2 inhibitors for CV outcomes in patients with T2DM independently of HF diagnosis demonstrated a superiority of empagliflozin as compared to dapagliflozin and canagliflozin in preventing all-cause and CV mortality (59). However, these differences might be based on the differing study populations, with our analysis particularly focusing on patients with $\mathrm{HF}$ at baseline rather than on the diabetes status. Further trials addressing the question of superiority within the SGLT2 inhibitor class are warranted.

We would like to put a special emphasis on the very low NNT of 17 for the composite outcome, which we have shown for the SGLT2 inhibitors in our meta-analysis. For comparison, in 2014, the PARADIGM-HF trial demonstrated a NNT of 32 for the prevention of $\mathrm{CV}$ mortality in patients with $\mathrm{HF}$ when treated with ARNIs, which are nowadays indispensable for treating $\mathrm{HF}$ (60). Of note is that our subgroup analysis showed no benefit for the concomitant use of SGLT2 inhibitors and ARNIs. However, that outcome was solely generated by the missing advantage of sotagliflozin use in addition to ARNI treatment in the SOLOIST-WHF and SCORED trials $(6,8)$, while the combination of dapagliflozin or empagliflozin with ARNIs resulted in beneficial effects, as demonstrated in a recent meta-analysis (61). Whether sotagliflozin constitutes as just an exception or whether these results were based on differences in the study population remains unclear. However, current data support the combined administration of these drug classes in patients with $\mathrm{HF}$ (62).

Hence, once more, our current meta-analysis emerges as highly relevant due to further confirming and demonstrating the outstanding properties of SGLT2 inhibitors in HF management in patients already on standard-of-care treatment.

\section{STRENGTHS OF THIS META-ANALYSIS AND DIFFERENCES AS COMPARED TO OTHER META-ANALYSES}

The most distinctive difference between our meta-analysis and other recent ones $(63,64)$ is that this is the first meta-analysis investigating all current RCTs on SGLT2 inhibitors on HF with clinical endpoints, irrespective of the size of the trial. Furthermore, we included all available data of post-hoc analyses from large trials to elaborate the safety and efficacy of SGLT2 inhibitors in patients with established HF at baseline, irrespective of their diabetes status. In addition we also focused on subgroups, especially the different types of HF, such as HFrEF and HFpEF, which is also a novel aspect.

\section{LIMITATIONS}

The major source of limitation is the different follow-up periods of the included studies, ranging from a minimum of 60 days to a maximum of 4.2 years. Furthermore, in some trials, the presence of $\mathrm{HF}$ at baseline was assessed by medical history only rather than echocardiographic parameters or biomarkers; hence, there is a chance that some patients with present heart failure were undiagnosed. Majority of the trials examined the most common SGLT2 inhibitors empagliflozin, dapagliflozin, and canagliflozin; for this reason, the cardioprotective results for these were the most prominent compared to those of sotagliflozin and ertugliflozin.

\section{CONCLUSION}

In conclusion, treatment with SGLT2 inhibitors showed robust results in reducing the incidences of $\mathrm{HHF}, \mathrm{CV}$ death, and allcause mortality in patients with underlying HF. Furthermore, the SGLT2 inhibitors appear to show a class effect. 


\section{DATA AVAILABILITY STATEMENT}

The original contributions presented in the study are included in the article/Supplementary Material, further inquiries can be directed to the corresponding author/s.

\section{AUTHOR CONTRIBUTIONS}

GMG and JMSM conceptualized the study and were involved in the acquisition and interpretation of the data. GMG, GG, and JMSM performed the statistical analysis. GMG drafted the manuscript. JMSM is the guarantor of the article. All authors were substantially involved in the critical revision of the manuscript, read, and approved the final version of the manuscript.

\section{REFERENCES}

1. Zinman B, Wanner C, Lachin JM, Fitchett D, Bluhmki E, Hantel S, et al. Empagliflozin, cardiovascular outcomes, and mortality in type 2 diabetes. $N$ Engl J Med. (2015) 373:2117-28. doi: 10.1056/NEJMoa1504720

2. McMurray JJV, Solomon SD, Inzucchi SE, Kober L, Kosiborod MN, Martinez FA, et al. Dapagliflozin in patients with heart failure and reduced ejection fraction. N Engl J Med. (2019) 381:1995-2008. doi: 10.1056/NEJMoa1911303

3. Wiviott SD, Raz I, Bonaca MP, Mosenzon O, Kato ET, Cahn A, et al. Dapagliflozin and cardiovascular outcomes in type 2 diabetes. $N$ Engl J Med. (2019) 380:347-57. doi: 10.1056/NEJMoa1812389

4. Perkovic V, Jardine MJ, Neal B, Bompoint S, Heerspink HJL, Charytan DM, et al. Canagliflozin and renal outcomes in type 2 diabetes and nephropathy. $N$ Engl J Med. (2019) 380:2295-306. doi: 10.1056/NEJMoa1811744

5. Neal B, Perkovic V, Mahaffey KW, de Zeeuw D, Fulcher G, Erondu N, et al. Canagliflozin and cardiovascular and renal events in type 2 diabetes. $\mathrm{N} \mathrm{Engl} \mathrm{J}$ Med. (2017) 377:644-57. doi: 10.1056/NEJMoa1611925

6. Bhatt DL, Szarek M, Steg PG, Cannon CP, Leiter LA, McGuire DK, et al. Sotagliflozin in patients with diabetes and recent worsening heart failure. $N$ Engl J Med. (2020) 384:117-28. doi: 10.1056/NEJMoa2030183

7. Cannon CP, Pratley R, Dagogo-Jack S, Mancuso J, Huyck S, Masiukiewicz U, et al. Cardiovascular outcomes with ertugliflozin in type 2 diabetes. $N$ Engl J Med. (2020) 383:1425-35. doi: 10.1056/NEJMoa2004967

8. Bhatt DL, Szarek M, Pitt B, Cannon CP, Leiter LA, McGuire DK, et al. Sotagliflozin in patients with diabetes and chronic kidney disease. N Engl J Med. (2020) 384:129-39. doi: 10.1056/NEJMoa2030186

9. Hsia DS, Grove O, Cefalu WT. An update on SGLT2 inhibitors for the treatment of diabetes mellitus. Curr Opin Endocrinol Diabetes Obes. (2017) 24:73. doi: 10.1097/MED.0000000000000311

10. Lupsa BC, Inzucchi SE. Use of SGLT2 inhibitors in type 2 diabetes: weighing the risks and benefits. Diabetologia. (2018) 61:2118-25. doi: 10.1007/s00125-018-4663-6

11. DeFronzo RA, Davidson J, Del Prato S. The role of the kidneys in glucose homeostasis: a new path towards normalizing glycaemia. Diabet Obes Metabol. (2012) 14:5-14. doi: 10.1111/j.1463-1326.2011.01511.x

12. Lopaschuk GD, Verma S. Mechanisms of cardiovascular benefits of sodium glucose co-Transporter 2 (SGLT2) inhibitors: a state-of-the-art review. JACC Basic Transl Sci. (2020) 5:632-44. doi: 10.1016/j.jacbts.2020.02.004

13. Kaplan A, Abidi E, El-Yazbi A, Eid A, Booz GW, Zouein FA. Direct cardiovascular impact of SGLT2 inhibitors: mechanisms and effects. Heart Fail Rev. (2018) 23:419-37. doi: 10.1007/s10741-017-9665-9

14. Tripolt NJ, Kolesnik E, Pferschy PN, Verheyen N, Ablasser K, Sailer S, et al. Impact of EMpagliflozin on cardiac function and biomarkers of heart failure in patients with acute MYocardial infarction-The EMMY trial. Am Heart J. (2020) 221:39-47. doi: 10.1016/j.ahj.2019.12.004

\section{FUNDING}

GMG is supported by a grant from the Austrian Science Fund (F 5404-B21). This research work was also supported by a grant from the Medical Research Agency (2019/ABM/01/00037-00).

\section{ACKNOWLEDGMENTS}

This paper was written by the members of the International Cardiovascular and Cardiometabolic Research Team (I-COMET; www.icomet.science).

\section{SUPPLEMENTARY MATERIAL}

The Supplementary Material for this article can be found online at: https://www.frontiersin.org/articles/10.3389/fcvm. 2021.691907/full\#supplementary-material

15. Siller-Matula JM, Pecen L, Patti G, Lucerna M, Kirchhof P, Lesiak M, et al. Heart failure subtypes and thromboembolic risk in patients with atrial fibrillation: The PREFER in AF-HF substudy. Int J Cardiol. (2018) 265:141-7. doi: 10.1016/j.ijcard.2018.04.093

16. Rohla M, Weiss TW, Pecen L, Patti G, Siller-Matula JM, Schnabel $\mathrm{RB}$, et al. Risk factors for thromboembolic and bleeding events in anticoagulated patients with atrial fibrillation: the prospective, multicentre observational PREvention oF thromboembolic events-European Registry in Atrial Fibrillation (PREFER in AF). BMJ Open. (2019) 9:e022478. doi: 10.1136/bmjopen-2018-022478

17. Gouya G, Siller-Matula JM, Fritzer-Szekeres M, Neuhold S, Storka A, Neuhofer LM, et al. Association of endostatin with mortality in patients with chronic heart failure. Eur J Clin Invest. (2014) 44:125-35. doi: 10.1111/eci.12197

18. Levy D, Kenchaiah S, Larson MG, Benjamin EJ, Kupka MJ, Ho KK, et al. Longterm trends in the incidence of and survival with heart failure. $N$ Engl J Med. (2002) 347:1397-402. doi: 10.1056/NEJMoa020265

19. Maggioni AP, Dahlström U, Filippatos G, Chioncel O, Leiro MC, Drozdz J, et al. EURObservational Research Programme: regional differences and 1-year follow-up results of the Heart Failure Pilot Survey (ESC-HF Pilot). Eur J Heart Fail. (2013) 15:808-17. doi: 10.1093/eurjhf/hft050

20. Ponikowski P, Voors AA, Anker SD, Bueno H, Cleland JG, Coats AJ, et al. 2016 ESC guidelines for the diagnosis treatment of acute chronic heart failure: the task force for the diagnosis treatment of acute chronic heart failure of the European Society of Cardiology (ESC). Developed with the special contribution of the Heart Failure Association (HFA) of the ESC. Eur J Heart Fail. (2016) 18:891-975. doi: 10.1002/ejhf.592

21. Chen Y-T, Wong LL, Liew OW, Richards AM. Heart Failure with Reduced Ejection Fraction (HFrEF) and Preserved Ejection Fraction (HFpEF): the diagnostic value of circulating microRNAs. Cells. (2019) 8:1651. doi: $10.3390 /$ cells 8121651

22. Borlaug BA, Redfield MM. Diastolic and systolic heart failure are distinct phenotypes within the heart failure spectrum. Circulation. (2011) 123:200614. doi: 10.1161/CIRCULATIONAHA.110.954388

23. Eyileten C, Postula M, Jakubik D, Toma A, Mirowska-Guzel D, Patti $\mathrm{G}$, et al. Non-Vitamin K Oral Anticoagulants (NOAC) Versus Vitamin $\mathrm{K}$ Antagonists (VKA) for atrial fibrillation with elective or urgent percutaneous coronary intervention: a meta-analysis with a particular focus on combination type. J Clin Med. (2020) 9:1120. doi: 10.3390/ jcm9041120

24. Gue YX, Spinthakis N, Farag M, Kubica J, Siller-Matula JM, Srinivasan $\mathrm{M}$ Gorog DA, et al. Impact of preadmission morphine on reinfarction in patients with st-elevation myocardial infarction treated with percutaneous coronary intervention: a meta-analysis. Clin Pharmacol Ther. (2020) 108:5462. doi: $10.1002 /$ cpt.1798 
25. Hofer F, Hengstenberg C, Goliasch G, Grygier M, Mascherbauer J, SillerMatula JM. Transcatheter versus surgical aortic valve replacement in lowrisk patients: a meta-analysis of randomized trials. Clin Res Cardiol. (2020) 109:761-75. doi: 10.1007/s00392-019-01571-2

26. Gelbenegger G, Postula M, Pecen L, Halvorsen S, Lesiak M, Schoergenhofer C, et al. Aspirin for primary prevention of cardiovascular disease: a metaanalysis with a particular focus on subgroups. BMC Med. (2019) 17:198. doi: 10.1186/s12916-019-1428-0

27. Komosa A, Lesiak M, Krasiński Z, Grygier M, Siniawski A, Skorupski $\mathrm{W}$, et al. Optimal timing of P2Y12 inhibitor loading in patients undergoing PCI: a meta-analysis. Thromb Haemost. (2019) 119:1000-20. doi: 10.1055/s-0039-1683421

28. Siller-Matula JM, Petre A, Delle-Karth G, Huber K, Ay C, Lordkipanidzé $\mathrm{M}$, et al. Impact of preoperative use of P2Y12 receptor inhibitors on clinical outcomes in cardiac and non-cardiac surgery: A systematic review and meta-analysis. Eur Heart J Acute Cardiovasc Care. (2017) 6:753-70. doi: $10.1177 / 2048872615585516$

29. Gouya G, Arrich J, Wolzt M, Huber K, Verheugt FW, Gurbel PA, et al. Antiplatelet treatment for prevention of cerebrovascular events in patients with vascular diseases: a systematic review and meta-analysis. Stroke. (2014) 45:492-503. doi: 10.1161/STROKEAHA.113.002590

30. Navarese EP, De Luca G, Castriota F, Kozinski M, Gurbel PA, Gibson $\mathrm{CM}$, et al. Low-molecular-weight heparins vs. unfractionated heparin in the setting of percutaneous coronary intervention for ST-elevation myocardial infarction: a meta-analysis. J Thromb Haemost. (2011) 9:1902-15. doi: 10.1111/j.1538-7836.2011.04445.x

31. Siller-Matula JM, Huber K, Christ G, Schror K, Kubica J, Herkner H Jilma $\mathrm{B}$, et al. Impact of clopidogrel loading dose on clinical outcome in patients undergoing percutaneous coronary intervention: a systematic review and meta-analysis. Heart. (2011) 97:98-105. doi: 10.1136/hrt.2010.195438

32. Siller-Matula JM, Jilma B, Schror K, Christ G, Huber K. Effect of proton pump inhibitors on clinical outcome in patients treated with clopidogrel: a systematic review and meta-analysis. J Thromb Haemost. (2010) 8:2624-41. doi: 10.1111/j.1538-7836.2010.04049.x

33. Damman K, Beusekamp JC, Boorsma EM, Swart HP, Smilde TD, Elvan A, et al. Randomized, double-blind, placebo-controlled, multicentre pilot study on the effects of empagliflozin on clinical outcomes in patients with acute decompensated heart failure (EMPA-RESPONSE-AHF). Eur J Heart Fail. (2020) 22:713-22. doi: 10.1002/ejhf.1713

34. Packer M, Anker SD, Butler J, Filippatos G, Pocock SJ, Carson P, et al. Cardiovascular and renal outcomes with empagliflozin in heart failure. $N$ Engl J Med. (2020) 383:1413-24. doi: 10.1056/NEJMoa2022190

35. Abraham WT, Ponikowski P, Brueckmann M, Zeller C, Macesic H, Peil B, et al. Rationale and design of the EMPERIAL-Preserved and EMPERIAL-Reduced trials of empagliflozin in patients with chronic heart failure. Eur J Heart Fail. (2019) 21:932-42. doi: 10.1002/ejhf.1486

36. Jensen J, Omar M, Kistorp C, Poulsen MK, Tuxen C, Gustafsson I, et al. Twelve weeks of treatment with empagliflozin in patients with heart failure and reduced ejection fraction: a double-blinded, randomized, and placebocontrolled trial. Am Heart J. (2020) 228:47-56. doi: 10.1016/j.ahj.2020.07.011

37. Mordi NA, Mordi IR, Singh JS, McCrimmon RJ, Struthers AD, Lang CC. Renal and cardiovascular effects of sglt2 inhibition in combination with loop diuretics in patients with type 2 diabetes and chronic heart failure: the RECEDE-CHF trial. Circulation. (2020) 142:1713-24. doi: 10.1161/CIRCULATIONAHA.120.048739

38. Lee MMY, Brooksbank KJM, Wetherall K, Mangion K, Roditi G, Campbell RT, et al. Effect of empagliflozin on left ventricular volumes in patients with type 2 diabetes, or prediabetes, and heart failure with reduced ejection fraction (SUGAR-DM-HF). Circulation. (2020) 143:516-25. doi: 10.1161/CIRCULATIONAHA.120.052186

39. Nassif ME, Windsor SL, Tang F, Khariton Y, Husain M, Inzucchi $\mathrm{SE}$, et al. Dapagliflozin effects on biomarkers, symptoms, and functional status in patients with heart failure with reduced ejection fraction: the DEFINE-HF trial. Circulation. (2019) 140:1463-76. doi: 10.1161/CIRCULATIONAHA.119.042929

40. Singh JSS, Mordi IR, Vickneson K, Fathi A, Donnan PT, Mohan M, et al. Dapagliflozin versus placebo on left ventricular remodeling in patients with diabetes and heart failure: the REFORM trial. Diabet Care. (2020) 43:1356-9. doi: $10.2337 / \mathrm{dc} 19-2187$

41. Tanaka A, Hisauchi I, Taguchi I, Sezai A, Toyoda S, Tomiyama H, et al. Effects of canagliflozin in patients with type 2 diabetes and chronic heart failure: a randomized trial (CANDLE). ESC Heart Fail. (2020) 7:1585-94. doi: 10.1093/ehjci/ehaa946.1151

42. Fitchett D, Zinman B, Wanner C, Lachin JM, Hantel S, Salsali A, et al. Heart failure outcomes with empagliflozin in patients with type 2 diabetes at high cardiovascular risk: results of the EMPA-REG OUTCOME ${ }^{\circledR}$ trial. Eur Heart J. (2016) 37:1526-34. doi: 10.1093/eurheartj/ehv728

43. Kato ET, Silverman MG, Mosenzon O, Zelniker TA, Cahn A, Furtado RH, et al. Effect of dapagliflozin on heart failure and mortality in type 2 diabetes mellitus. Circulation. (2019) 139:2528-36. doi: 10.1161/CIRCULATIONAHA.119.040130

44. Radholm K, Figtree G, Perkovic V, Solomon SD, Mahaffey KW, de Zeeuw D, et al. Canagliflozin and heart failure in type 2 diabetes mellitus. Circulation. (2018) 138:458-68. doi: 10.1161/CIRCULATIONAHA.118.034222

45. Sarraju A, Li J, Cannon CP, Chang TI, Agarwal R, Bakris G, et al. Effects of canagliflozin on cardiovascular, renal, and safety outcomes in participants with type 2 diabetes and chronic kidney disease according to history of heart failure: results from the CREDENCE trial. Am Heart J. (2020) 233:141-8. doi: 10.1016/j.ahj.2020.12.008

46. Cosentino F, Cannon CP, Cherney DZI, Masiukiewicz U, Pratley R, DagogoJack S, et al. Efficacy of ertugliflozin on heart failure-related events in patients with type 2 diabetes mellitus and established atherosclerotic cardiovascular disease: results of the VERTIS CV trial. Circulation. (2020) 142:2205-15. doi: 10.1161/CIRCULATIONAHA.120.050255

47. Petrie MC, Verma S, Docherty KF, Inzucchi SE, Anand I, Bělohlávek J, et al. Effect of dapagliflozin on worsening heart failure and cardiovascular death in patients with heart failure with and without diabetes. JAMA. (2020) 323:1353-68. doi: 10.1001/jama.2020.1906

48. Docherty KF, Jhund PS, Inzucchi SE, Køber L, Kosiborod MN, Martinez FA, et al. Effects of dapagliflozin in DAPA-HF according to background heart failure therapy. Eur Heart J. (2020) 41:2379-92. doi: 10.1093/eurheartj/ehaa183

49. Fitchett D, Butler J, van de Borne P, Zinman B, Lachin JM, Wanner C, et al. Effects of empagliflozin on risk for cardiovascular death and heart failure hospitalization across the spectrum of heart failure risk in the EMPA-REG OUTCOME(R) trial. Eur Heart J. (2018) 39:363-70. doi: 10.1093/eurheartj/ehx511

50. Singh AK, Singh R. Heart failure hospitalization with SGLT-2 inhibitors: a systematic review and meta-analysis of randomized controlled and observational studies. Expert Rev Clin Pharmacol. (2019) 12:299-308. doi: 10.1080/17512433.2019.1588110

51. Zelniker TA, Wiviott SD, Raz I, Im K, Goodrich EL, Bonaca MP, et al. SGLT2 inhibitors for primary and secondary prevention of cardiovascular and renal outcomes in type 2 diabetes: a systematic review and metaanalysis of cardiovascular outcome trials. Lancet. (2019) 393:31-9. doi: 10.1016/S0140-6736(18)32590-X

52. Berliner D, Bauersachs J. Current drug therapy in chronic heart failure: the new guidelines of the European Society of Cardiology (ESC). Kor Circ J. (2017) 47:543-54. doi: 10.4070/kcj.2017.0030

53. Mentz RJ, Kelly JP, von Lueder TG, Voors AA, Lam CS, Cowie MR, et al. Noncardiac comorbidities in heart failure with reduced versus preserved ejection fraction. J Am Coll Cardiol. (2014) 64:2281-93. doi: 10.1016/j.jacc.2014.08.036

54. Paulus WJ, Tschöpe C. A novel paradigm for heart failure with preserved ejection fraction: comorbidities drive myocardial dysfunction and remodeling through coronary microvascular endothelial inflammation. J Am Coll Cardiol. (2013) 62:263-71. doi: 10.1016/j.jacc.2013.02.092

55. Anker SD, Butler J, Filippatos GS, Jamal W, Salsali A, Schnee J, et al. Evaluation of the effects of sodium-glucose co-transporter 2 inhibition with empagliflozin on morbidity and mortality in patients with chronic heart failure and a preserved ejection fraction: rationale for and design of the EMPERORpreserved trial. Eur J Heart Fail. (2019) 21:1279-87. doi: 10.1002/ejhf.1596

56. Williams DM, Evans M. Dapagliflozin for heart failure with preserved ejection fraction: will the DELIVER study deliver? Diabetes Ther. (2020) 11:2207-19. doi: 10.1007/s13300-020-00911-0 
57. van Deursen VM, Urso R, Laroche C, Damman K, Dahlström U, Tavazzi $\mathrm{L}$, et al. Co-morbidities in patients with heart failure: an analysis of the European Heart Failure Pilot Survey. Eur J Heart Fail. (2014) 16:103-11. doi: 10.1002/ejhf.30

58. Tousoulis D, Oikonomou E, Siasos G, Stefanadis C. Diabetes mellitus and heart failure. Eur Cardiol. (2014) 9:37-42. doi: 10.15420/ecr.2014.9.1.37

59. Täger T, Atar D, Agewall S, Katus HA, Grundtvig M, Cleland JG, et al. Comparative efficacy of sodium-glucose cotransporter-2 inhibitors (SGLT2i) for cardiovascular outcomes in type 2 diabetes: a systematic review and network meta-analysis of randomised controlled trials. Heart Fail Rev. (2020). doi: 10.1007/s10741-020-09954-8. [Epub ahead of print].

60. McMurray JJ, Packer M, Desai AS, Gong J, Lefkowitz MP, Rizkala AR, et al. Angiotensin-neprilysin inhibition versus enalapril in heart failure. $N$ Engl J Med. (2014) 371:993-1004. doi: 10.1056/NEJMoa1409077

61. Yan Y, Liu B, Du J, Wang J, Jing X, Liu Y, et al. SGLT2i versus ARNI in heart failure with reduced ejection fraction: a systematic review and meta-analysis. ESC Heart Fail. (2021) 8:2210-9. doi: 10.1002/ehf2.13313

62. Bauersachs J. Heart failure drug treatment: the fantastic four. Eur Heart J. (2021) 42:681-3. doi: 10.1093/eurheartj/eha a1012

63. Zannad F, Ferreira JP, Pocock SJ, Anker SD, Butler J, Filippatos G, et al. SGLT2 inhibitors in patients with heart failure with reduced ejection fraction: a meta-analysis of the EMPEROR-Reduced and DAPAHF trials. Lancet. (2020) 396:819-29. doi: 10.1016/S0140-6736(20)3 1824-9
64. Chambergo-Michilot D, Tauma-Arrué A, Loli-Guevara S. Effects and safety of SGLT2 inhibitors compared to placebo in patients with heart failure: a systematic review and meta-analysis. Int J Cardiol Heart Vasc. (2021) 32:100690. doi: 10.1016/j.ijcha.2020.100690

Conflict of Interest: DL has unrestricted research grants from Boehringer Ingelheim, MSD, and Novartis; is on the Speakers' Bureau of Astra Zeneca, Bayer, Boehringer Ingelheim, and NovoNordisk; and is an advisor for Bayer. HS has unrestricted research grants from Boehringer Ingelheim, Eli Lilly, MSD, NovoNordisk, and Sanofi and is on the Speakers' Bureau of AstraZeneca, Amgen, Boehringer Ingelheim, BMS, Eli Lilly, NovoNordisk, Novartis, and Sanofi. JMSM received lecture fees from Bayer, Daiichi, Chiesi and BMS, unrelated to this publication.

The remaining authors declare that the research was conducted in the absence of any commercial or financial relationships that could be construed as a potential conflict of interest.

Copyright (C) 2021 Gager, Gelbenegger, Jilma, von Lewinski, Sourij, Eyileten, Filipiak, Postula and Siller-Matula. This is an open-access article distributed under the terms of the Creative Commons Attribution License (CC BY). The use, distribution or reproduction in other forums is permitted, provided the original author(s) and the copyright owner(s) are credited and that the original publication in this journal is cited, in accordance with accepted academic practice. No use, distribution or reproduction is permitted which does not comply with these terms. 